\title{
BUILDING BETTER LAW: HOW DESIGN THINKING CAN HELP US BE BETTER LAWYERS, MEET NEW CHALLENGES, AND CREATE THE FUTURE OF LAW
}

\author{
Susan Ursel*
}

The legal profession faces increasing challenges to the relevance, utility, and acceptance of law and the rule of law as tools of social organization that are important and essential to human beings. Often the issues which challenge law and legal systems seem perennial, obstinate, and intractable. In order to remain relevant to the societies it serves, the law needs to innovate. We need to find new ways of thinking about law as a human designed and deliberate system of social organization. In this context, adopting an innovation mindset is an important starting point. "Design thinking" offers us a description and practice of an innovation mindset that can be and is employed in a variety of professional contexts. This article is an introduction to design thinking, its challenges, and its possibilities for law. It postulates that in fact design thinking as a concept and as a set of techniques is particularly well suited for use in law, and that we actually employ many of its techniques already. The article argues that by bringing these techniques into sharper focus, we can both recognize how we are in some ways using them already, and more importantly, how they can be deployed in even more useful and innovative ways to "build better law" at all scales of the legal endeavour, from individual service to legal systems.

La profession juridique doit relever des défis croissants liés à la pertinence, à l'utilité et à l'acceptation du droit et de la règle de droit comme outils d'organisation sociale qui sont importants, voire essentiels pour l'être humain. Les problèmes qui minent le droit et les systèmes juridiques semblent souvent permanents, tenaces et insolubles. Pour que le droit demeure pertinent à l'endroit des sociétés qu'il dessert, nous devons lui donner un souffle nouveau et trouver de nouvelles façons de le considérer comme un système d'organisation sociale conçu par l'être humain et mûrement réfléchi. Dans ce contexte, l'adoption d'un état d'esprit axé sur l'innovation représente un important point de départ. La "pensée conceptuelle " ouvre la voie à l'adoption d'un esprit axé sur l'innovation qui peut être utilisé dans plusieurs contextes professionnels, s'il ne l'est pas déjà. Dans cet article l'auteur aborde la pensée conceptuelle, les enjeux qu'elle comporte et les possibilités qu'elle offre pour le droit. Il fait valoir que tant les fondements théoriques que la pratique

* Susan Ursel is Senior Partner with Ursel Phillips Fellows Hopkinson LLP. A lawyer for over thirty years, her labour and employment practice has had a special focus on social justice issues, including access to justice. Pursuing progressive legal change for her clients, she has appeared in the Supreme Court of Canada and other courts and tribunals on a variety of precedent-setting Charter and human rights cases. Seeking to drive innovation in law and legal services, Ursel has been the founding member or director of many significant initiatives in the profession and the community at large. She was recognized for her work on access to justice in the spring of 2016 when she was honoured with the Lifetime Achievement Award from Pro Bono Ontario. A “lifelong student," Ursel successfully completed Dr Frances Westley's groundbreaking graduate diploma in social innovation as part of the inaugural class in 2012. The diploma was established by the University of Waterloo, affiliated with Social Innovation Generation at Waterloo, in partnership with the J.W. McConnell Family Foundation and in collaboration with the Schulich School of Business at York University. As part of her commitment to the profession, she continues to look for new and better ways to do law in the twenty-first century. 
de la pensée conceptuelle peuvent être adaptés au droit et que, effectivement, nous utilisons déjà bon nombre des techniques en question. En portant davantage notre attention sur ces aspects pratiques, affirme l'auteur, nous pourrons mieux comprendre en quoi nous les utilisons déjà à certains égards et, surtout, déterminer comment nous pouvons les exploiter sous des formes encore plus utiles et plus novatrices afin de faire progresser le droit à tous les niveaux de l'activité juridique, depuis les services individuels jusqu'aux systèmes juridiques.

\section{INTRODUCTION: WHY DESIGN THINKING? WHY NOW?}

The interesting and challenging thing about this moment is that we know the old forms aren't working. But we can't yet see what the new forms will be. We are making them up in "real time"; we're even re-imagining time.

- Krista Tippett, Becoming Wise: An Inquiry into the Mystery and Art of Living

\section{A. Introduction}

In our world, in this still new century, we in the legal profession face increasing challenges to the relevance, utility, and acceptance of law and the rule of law as tools of social organization that are important and essential to human beings. ${ }^{1}$ Law as a system is facing a crisis of legitimacy and workability on many fronts, even as it remains an important organizing principle of modern society at all scales. ${ }^{2}$ The $^{2}$ Hague Institute for Innovation and Law (HiiL) highlights this crisis of legitimacy on its website page, stressing the need to improve international justice systems to accommodate the needs of their users. The institute argues that in order to restore public confidence in a failing justice system, it must adopt models and procedures that do not simply repeat the same kind of thinking that generated the problems in the first place, and that instead "close the gap between those who have access to justice and those who don't." These observations do not just have application to international law; they are a concise statement of the issues that bedevil domestic law in common and civil law jurisdictions around the globe as well as here in Canada.

Many of us in the legal profession are concerned with the problems we see in our everyday lives: access to justice; respect for the rule of law; democratic and representative law creation; how to make the business of law both viable and useful to our clients, to name just a few. And, yet, those issues seem perennial, obstinate, and intractable. To take just one example - access to justice - we seem unable to solve the problem of ensuring equitable, fair, and efficient access to dispute resolution practices. To quote legal scholars Kent Roach and Lorne Sossin in in their 2010 consideration of Michael Trebilcock's approach to

1 See, eg, Action Committee on Access to Justice in Civil and Family Matters, “Access to Civil and Family Justice: A Roadmap for Change" (October 2013), online: <http://www.cfcj-

fcjc.org/sites/default/files/docs/2013/AC_Report_English_Final.pdf>; see also Canadian Bar Association (CBA),

"Reaching Equal Justice: An Invitation to Envision and Act" (November 2013), online:

$<$ http://www.cba.org/CBAMediaLibrary/cba_na/images/Equal\%20Justice\%20-

\%20Microsite/PDFs/EqualJusticeFinalReport-eng.pdf $>$.

2 Geoff Mulgan, “The Process of Social Innovation” in Steven Johnson, ed, The Innovator's Cookbook (New York: Riverhead Books, 2011) at 162-164.

3 From Hague Institute for Innovation of Law (HiiL), “Why Do We Exist?” online: <http://www.hiil.org/about-us>. 
access to justice, "“[m]uch ink has been spilled about the crisis of access to justice in Canada. Much less ink has been devoted to how the crisis might be solved." ${ }^{5}$ Despite the efforts of these scholars, we have been talking about trying to solve this issue for decades. In some significant way, we as a profession seem to be stuck. To properly address these concerns, we must therefore search for and use the best tools we have available to us. We cannot remain stuck.

In this context, it is becoming clear to many in our profession that the law needs to innovate to remain relevant to the societies it serves. We need to find new ways of thinking about law as a human designed and deliberate system of social organization, in order to innovate. ${ }^{6}$ The same kinds of thinking and responses that brought us to this point will not carry us beyond it or answer the pressing questions we face. Our work must encompass creating new models for conveying an understanding of law both to those in the profession and to lay persons; evolving new ways of thinking about law and the project of law in its broadest sense ${ }^{7}$; as well as dealing with the more familiar questions of access to justice, and legal services and technology, that have come to dominate discussions about legal innovation.

Innovation is often conceived of as an entrepreneurial or technological activity. Its techniques can also be harnessed to other purposes though. "Social innovation," as a variety of this activity, seeks to apply innovation techniques to social or institutional issues. Conceived of as a field that is intended to create useful and transformational change at a fundamental systems level, in a complex world, ${ }^{8}$ social innovation is about "changing the system dynamics that created the problem in the first place." 9 This is precisely the innovation challenge facing law when it confronts such large-scale process issues as access to justice and the provision of timely justice. Frances Westley and her research partners at the University of Waterloo Institute for Social Innovation and Resilience draw on this view of social innovation as requiring the transformation of a system at the very broadest level (for example, changes in culture, laws, policy, economy, and so on). ${ }^{10}$ If we take the view that law is a "meta-system" that organizes many other systems, then impacting the legal system also has the potential to answer problems both inside of law/legal practice and, more broadly, across other systems, communities, societies, and cultures. ${ }^{11}$

4 Kent Roach \& Lorne Sossin, “Access to Justice and Beyond” (2010) 60 UTLJ 373; see also Brian Etherington,

"Promises, Promises: Notes on Diversity and Access to Justice” (2000) 26:1 Queen's LJ 43.

$5 \quad$ Ibid at 373.

6 For more on the human design perspective of innovating see HiiL, supra note 3.

7 By the concept "project of law," I mean to suggest our understanding of, theorizing about, and practice of law at all scales. As part of this discussion, we need to fundamentally consider (and perhaps reconsider in an iterative way) what we want and expect out of our legal system such that it should serve the individuals and communities who are bound by it.

8 Frances Westley \& Sam Laban, "Social Innovation: Creating Transformational Change in a Complex World” in Social Innovation Lab Guide (Waterloo: University of Waterloo Institute for Social Innovation and Resilience, 2015), online: $<$ https://sig.app.box.com/s/7kj1oo1hs2bavzcyuh7krdb0nuw9h13x>.

$9 \quad$ Ibid.

10 Ibid.

11 Law as a "meta-system" was a concept suggested to me by Frances Westley during her graduate diploma in social innovation program at University of Waterloo in 2011-2012. I am grateful for her idea, although any applications of it in this article are strictly my own, and she should not be held responsible. 
Institutional responses to these challenges for the legal profession, ${ }^{12}$ legal educational institutions, ${ }^{13}$ as well as governmental actors ${ }^{14}$ responsible for legal services ${ }^{15}$ are beginning to gain momentum in Canada. They represent a beginning recognition of the need for innovation. The Canadian Bar Association [CBA] recognizes the role of innovation in this work and has set an action plan to take a leadership role in promoting innovation in the legal profession by facilitating and promoting national dialogue, innovation incubators, a national investment fund, and some other measures geared towards innovation. ${ }^{16}$ These would provide some scaffolding or structure within which innovation can occur. The CBA has followed up this starting point with further work on the braided issues of innovation in law and prospects for young lawyers, with its recent report "Do Law Differently: Futures for Young Lawyers." "In this report, the authors identify a number of educational directions that young lawyers should take, among them process improvement, entrepreneurial spirit, and strategic thinking. An innovation mindset, which embraces the possibilities of revitalization, invention, and change, is going to be critically important for future lawyers.

While adopting an innovation mindset is an important starting point, there are still a number of practical fundamental questions that remain. For instance, what exactly is an "innovation mindset"? How do we use it to "do innovation work"? What tools do we have or could we create to meet this innovation challenge, without falling into what some have called the "innovation gap" - the often yawning chasm between innovation expectations and innovation results? ${ }^{18}$ Design thinking - or, as it is often called in the academic literature, designerly thinking - offers us a description and practice of the innovation mindset that we are being called to employ. Evolving over the past five decades, design thinking has moved from a discipline-based concept concerned with the creation of artefacts (as in engineering, architecture, and computer and cybernetic sciences), to a more broadly applicable concept and set of practices most recently adopted by business, management, and entrepreneurs. ${ }^{19}$ Innovation and, more particularly, social

12 Eg, see the CBA's Legal Futures Initiative, which seeks to understand and offer insights into the changing Canadian legal marketplace. For a further discussion on the value of lawyers and opportunities for change in such a marketplace, see CBA Legal Futures Initiative, Futures: Transforming the Delivery of Legal Services in Canada (Ottawa: CBA, 2014), online: $<$ http://www.cba.org/CBAMediaLibrary/cba_na/PDFs/CBA\%20Legal\%20Futures\%20PDFS/FuturesFinal-eng.pdf $>$.

13 See Osgoode Hall, "Winkler Institute on Dispute Resolution," online $<$ http://winklerinstitute.ca $>$; see also Dean Lorne Sossin, "Law School by Design," blog (22 September 2015), online: <http://deansblog.osgoode.yorku.ca/2015/09/lawschool-by-design/>.

14 See SiG Knowledge Hub, "Introduction to Public Sector Innovation," online: <http://sigknowledgehub.com/2012/06/01/introduction-topublic-sector-innovation/>.

15 The Ontario Ministry of the Attorney General's Innovation Office, eg, was established in 2014 to "lead a coordinated, incremental approach to justice system modernization." Ontario, Ministry of the Attorney, "General Estimates Briefing Book 2015-16" (November 2015), online:

$<$ http://www.attorneygeneral.jus.gov.on.ca/english/about/pubs/mag_annual/ppar_2015_16/index.html>.

16 CBA, supra note 1 at 74.

17 CBA \& Jordan Furlong, "Do Law Differently: Futures for Young Lawyers" (February 2016), online: $<$ https://www.cba.org/getattachment/Publications-Resources/Resources/Futures/DO-LAW-DIFFERENTLY-FUTURESFOR-YOUNG-LAWYERS/NewLawforNewLawyersEng.pdf>.

18 For a more fulsome explanation of the "innovation gap" as a concept, see Leah Richler, "Is There an Innovation Gap in Canada?" Globe and Mail (15 August 2014), online: <http://www.theglobeandmail.com/report-onbusiness/careers/career-advice/life-at-work/is-there-an-innovation-gap-in-canada/article20078592/>; see also David S Weiss and Claude P LeGrand, "The Innovation Gap" (2011), online: InnovationManagement.se, $<$ http://www.innovationmanagement.se/2011/05/27/the-innovation-gap/>.

19 For an analysis of design-thinking concepts and theories, as well as a helpful literature review, see Ulla JohanssonSköldberg, Jill Woodilla \& Mehves Çetinkaya, "Design Thinking: Past, Present and Possible Futures" (2013) 20:2 Creativity and Innovation Management 122, online $<$ https://s3.amazonaws.com/academia.edu.documents/46604512/Design_Thinking_Past_Present_and_Possibl2016061876561c5psgb.pdf?AWSAccessKeyId=AKIAIWOWYYGZ2 
innovation are the close cousins of design thinking. Some theories of social innovation, moreover, explicitly recognize their roots in design thinking. ${ }^{20}$ Indeed, it might be said that innovation is design thinking in action.

As a discipline, design thinking has been deployed across many fields and professions, including engineering, business, and health care, but it is not so well known to lawyers and our profession. Design thinking is a kind of "innovation mindset." It can be a doorway into innovation in law. ${ }^{21}$ This article is an introduction to design thinking, its challenges, and its possibilities for law.

\section{B. Design Thinking and Law}

Law as a system is not necessarily seen or practised as a creative process. As Mark Szabo, vice president of Karo Group in Calgary, notes,

[a]t first blush, the practice of law does not seem like fertile territory for design thinking. According to David Maister, "In a room full of lawyers, any idea, no matter how brilliant, will be instantly attacked." He goes on to say, "In other businesses, innovative thinking and action are considered a primary requirement for success. ... Lawyers are usually different. Presented with a new business idea, the first thing they ask is, 'Which other law firms are doing this?"' There is good reason for the reluctance to innovate. Lawyers are trained to understand a legal system, apply laws to specific sets of facts, and resolve the ambiguous space between the two. To accomplish this, they are trained to call upon past applications of law to facts, using legal precedent to guide the answer. In the terminology of Roger Martin's The Business of Design, the legal system places an extremely high value on reliability - the application of the past to determine a future course of action. ${ }^{22}$

Y53UL3A\&Expires=1507864467\& Signature $=$ gSHC11 ApDaJdBTBgMa17EhDSsjc\%3D\&responsecontentdisposition=inline $\% 3$ B\%20file-name\%3DDesign_Thinking_Past_Present_and_Possibl.pdf $>$. I have adopted in this article these authors' distinctions between the literature on "designerly thinking," which in the main emanates from the design academy and is a self-reflective discourse on the work and thinking processes of designers, and the literature and more popular writing on "design thinking" that has emerged in business and management discourse predominantly. I would contend that both sources have value and interest in developing a concept of design in law since the former provides a rich and more developed discussion of the process, while the latter provides accessible and user-friendly models of design thinking that are suggested as adaptable in a variety of circumstances. See also Lotta Hassi \& Miko Laasko, "Conceptions of Design Thinking in the Management Discourse" (European Academy of Design Biennial Conference, Porto, Portugal, 2011), online $<$ http://www.mind-space.fi/wpcontent/uploads/2013/12/HassiLaakso_IASDR_FINAL.pdf $>$.

20 See Frances Westley \& Sam Laban, “Antecedents to Social Innovation Labs: Design Labs" in Social Innovation Lab Guide (Waterloo: University of Waterloo Institute for Social Innovation and Resilience, 2015), online:

$<$ https://uwaterloo.ca/waterloo-institute-for-social-innovation-and-resilience/projects/social-innovation-lab-guide>; for a synopsis of the characteristics of social innovation labs, see Lidia Gryszkiewicz, Tuukka Toivonen \& Ionna Lykourentzou, "Innovation Labs: 10 Defining Features" Stanford Social Innovation Review (3 November 2016), online: $<$ https://ssir.org/articles/entry/innovation_labs_10_defining_features>; see also Per-Anders Hillgren, Anna Seravalli \& Anders Emilson, "Prototyping and Infrastructuring in Design for Social Innovation" (2011) 7:3-4 CoDesign: International Journal of CoCreation in Design and the Arts 169; Adam Thorpe \& Lorraine Gamman, "Design with Society: Why Socially Responsive Design Is Good Enough" (2011) 7:3-4 CoDesign: International Journal of CoCreation in Design and the Arts 217; Barry Wylant, "Design Thinking and the Experience of Innovation" (2008) 24:2 MIT Design Issues 3; Enzio Manzini “Making Things Happen: Social Innovation and Design” (2014) 30:1 MIT Design Issues 57; Geoff Mulgan, "Design in Public and Social Innovation: What Works, And What Could Work Better" (Nesta), online: $<$ https://www.nesta.org.uk/sites/default/files/design_what_works_what_could_work_better.pdf $\geq$.

21 Johansson-Sköldberg, Woodilla \& Çetinkaya, supra note 19 at $127-\overline{1} 28$.

22 Szabo, infra note 40 at 44. 
Law has its own inherent resistance points to the more free-flowing processes, comfort with indeterminacy and uncertainty, and sheer experimentation inherent in design thinking. Law and legal professionals, because of their very nature, can generate their own "stuckness" or resistance to new ideas exactly at the point where innovation is necessary. But there are contexts in which legal creativity is not just desirable but also a necessity in order to allow for continuing relevance and utility. Articulating the place of design thinking in law allows us to acknowledge the role and legitimacy of creativity in law and provides us with the option of using creative processes in our profession. Design thinking holds out the possibility of becoming "unstuck" and moving forward into solutions.

Design and design thinking are not new concepts. ${ }^{23}$ Indeed, Rim Razzouk and Valerie Shute, educators interested in the applications of design thinking, describe design thinking as a "natural and ubiquitous human activity" akin to problem solving. Like problem solving, the design process comes as a creative response to a dissatisfied state of affairs. ${ }^{24} \mathrm{We}$ often associate design with the tangible world: cars, clothes, computers, furniture, art - the stuff of life. Perhaps we also recognize its place in the work of creating less tangible, but nevertheless present, artefacts, like iPhone applications, computer programs, and engineering processes. Design thinking, broadly speaking, is a conceptualization of what we do when we set out to create something new in response to a need or a demand. Writing about design thinking attempts to describe the cognitive processes identified with this creative intellectual act. It further attempts to codify a set of identifiable, replicable processes or methodologies through which design itself can happen. Because of their adaptability and usefulness to many and different contexts, design and design thinking have infiltrated their way into even more intangible, yet very human, activities: business and entrepreneurial innovations; ${ }^{25}$ financial services; ${ }^{26}$ organizational design and service delivery; ${ }^{27}$ and health care provision, ${ }^{28}$ to name but a few examples.

Businesses and business schools have been at the forefront of bringing this "way of thinking" into their worlds precisely because of its ability to help solve some of the questions that field faces. Design thinking, as will be discussed, offers a way into thinking about complexity in systems ${ }^{29}$ and solving the "wicked questions" that such complexity generates. ${ }^{30}$ Design and design thinking are starting to emerge in law.

23 Ibid.

24 Rim Razzouk \& Valerie Shute, "What Is Design Thinking and Why Is It Important? (2012) 82:3 Review of Educational Research 330 at 330.

25 See eg, Roger Martin \& Karen Christensen, eds, Rotman on Design: The Best on Design Thinking from Rotman Magazine (Toronto: University of Toronto Press, 2013).

26 Tim Brown, Change by Design (New York: Harper Business, 2009) at 119-121 [Brown, Change by Design].

27 Jon Kolko, "Design Thinking Comes of Age," Harvard Business Review (September 2015), online: $<$ https://hbr.org/2015/09/design-thinking-comes-of-age $>$.

28 Brown, Change by Design, supra note 26 at 50-53; see also Sholom Glouberman \& Brenda Zimmerman, Complicated and Complex Systems: What Would Successful Reform of Medicare Look Like? Commission on the Future of Health Care in Canada Discussion Paper no 8 (July 2002).

29 The Plexis Institute describes complexity in this context as occurring when various elements within a system work collectively to create amazing emergent behaviours. For a more fulsome discussion of complexity in systems, see Plexus Institute, "Complexity," online: <http:/www.plexusinstitute.org/?page=complexity $>$.

30 A "wicked question" according to Mark Holmgren, citing the Tamarak Institute, is one that "articulates an embedded and often contradictory assumption that we hold about an issue, context, or organization". See https://markholmgren.com/2013/09/11/upside-down-thinking/ >. See also Richard Buchanan, infra note 42, for his discussion of the use and meaning of "wicked problems" in the activity of design thinking. 
Projects such as the Legal Design Lab, ${ }^{31}$ based at Stanford Law School and d.school, ${ }^{32}$ are using design thinking to generate solutions to problems and issues in law as well as working to embed design thinking into legal education, business, and practice. Margaret Hagan's Open Law Lab at Stanford Law School ${ }^{33}$ also adopts the design-thinking approach by "document[ing] past, current, and possible initiatives that can increase access to justice through technology \& design."34 One of the initiatives flowing from Hagan's work, for example, is the "illustrative law" approach to legal design, which seeks to take text-heavy legal resources and convert them into user-friendly visually palpable displays. ${ }^{35}$ Organizations in Canada such as Pro Bono Ontario, ${ }^{36}$ while not explicitly created with a design philosophy, practice "design thinking" in imagining, creating, and developing programs in the profession that will bring pro bono services to under- or not-served communities. These innovative programs are just one answer to the pressing need for access to justice that our legal system is currently experiencing. ${ }^{37}$

Despite its relative newness as a concept in law, design thinking within the practice of law does happen whether we expressly recognize it or not. It happens in moments such as an inspired legal argument born of years of working within a litigation context, that then creates new precedents that address emerging substantive issues in law. It happens in systemic contexts, which themselves may be ad hoc, intentional, or simply opportunities for change. An example of this from my own experience was the 1990s movement towards social and legal reform for lesbian and gay citizens in Ontario and across Canada. In that context, the lesbian, gay, bisexual, and trans [LGBT] communities designed (sometimes on the fly) an approach to legal reform that was intended both to achieve specific legal results and support the social recognition of LGBT rights. Concepts such as "same-sex relationships" were introduced into the law as much as a decade before same-sex marriage was recognized in Canada. Through the use of innovative ways to reimagine and understand these relationships, the idea of same-sex marriage was rendered possible. Innovation built upon innovation. Design thinking also happens in law firms, in-house law departments, and legal clinics when service issues arise. Finally, design thinking happens in spaces deliberately created as "legal design studios" like the Legal Design Lab at Stanford University or the Legal Innovation Zone at Ryerson University in Toronto. ${ }^{38}$ There, needs and pressing problems in law, especially in legal processes at all levels of scale, are addressed through the creation of innovative uses of technology and social media. These are examples of design thinking in action in law. ${ }^{39}$

Design thinking could help us get unstuck in our thinking and innovation when we are dealing with obstinate, recurring problems like access to justice, the viability of the billable hour, and the provision of efficient legal services. Despite its potential, there is, as of yet, little actual writing about the process of

31 The Legal Design Lab describes itself as "working at the intersection of human-centered design, technology and law to build a new generation of legal products and services." See Legal Design Lab, "Home” (undated), online:

$<$ http://www.legaltechdesign.com>.

32 The design school associated with Stanford University, also known as the Institute of Design at Stanford. See Hasso Plattner Institute of Design at Stanford, “d.school," online: $<$ http://dschool.stanford.edu $>$.

33 See Open Law Lab, “About” (undated), online: < http://www.openlawlab.com/about/>.

34 Ibid.

35 See Open Law Lab, "Visual Law" (undated), online: <http://www.openlawlab.com/project-topics/illustrated-lawvisualizations/>.

36 See Pro Bono Law Ontario, "Home" (undated), online: $<$ https://www.pblo.org $>$.

37 In the interests of full transparency, I should note that I was on the founding board of Pro Bono Law Ontario or PBLO, as it was then called.

38 Legal Innovation Zone, “About Us" (undated), online: <http://www.legalinnovationzone.ca/about-us/>.

39 See Legal Innovation Zone, "Startups" (undated), online: $<$ http://www.legalinnovationzone.ca/startups/>, for a listing of examples of such innovations. 
design thinking in the context of law. ${ }^{40}$ This article attempts to provide an introduction to design thinking concepts and advance the discussion of its application in law.

\section{Outline of the Article}

Exploring some definitions of design thinking as they have evolved in a variety of professional settings, this article first sets the stage for understanding what design thinking itself is in Part I. This section considers design as a concept and as a cognitive style with a particular emphasis on abductive reasoning, ${ }^{41}$ and concludes with an extended consideration of the methodology of design thinking - that is, what it looks like in action. Building on these ideas, the article considers in Parts II, III, and IV the application of design thinking to work in law, exploring the similarities and tensions between how we traditionally approach problem solving in law and how design thinking might inform this work. In Part IV, the article continues with a consideration of the practical application of design thinking, including some examples of design spaces in law in which this work is being done. Finally, in the conclusion, I offer some thoughts on where design thinking could take the practice, profession, and art of law and some ideas for further exploration and consideration in aid of getting us "unstuck."

\section{DESIGN THINKING: WAYS TO UNDERSTAND ITS APPLICABILITY AND USEFULNESS}

\section{A. Design Thinking Might Be Useful to Law but What Exactly is it?}

Design thinking is touted in a variety of fields as useful, necessary, or even essential as an answer to dealing with complex problems, issues, and challenges. Yet the discussion of what design thinking is, outside the design field itself, is often unclear and not as convincing as it could be because of this. While its enthusiasts are sincere, its message sometimes remains obscure. For these reasons, it may be helpful to delve into understanding what design thinking is and how it is done, as those who are using it describe it. By doing this, we may come to an appreciation of the value and challenges that it presents to those interested in both law and innovation.

\section{Design as a Concept}

What do we mean when we use the term design? In 1992, Richard Buchanan traced the evolution of the concept of design from "a trade activity to a segmented profession to a field for technical research ... to what now should be recognized as a new liberal art of technological culture." ${ }^{, 2}$ He argued for the recognition of a "common discipline of design thinking," which crosses disciplinary boundaries and is applied in virtually all domains of human activity since it is concerned with solutions to "wicked problems" through the creation of the artificial, or human conceived and created, answer. ${ }^{43}$ Internationally

40 Much of the commentary at this point is relatively anecdotal and represents an emerging interest in the topic. See, eg, Mark Szabo, "Design Thinking in Legal Practice Management" (2010) 21:3 Design Management Review 44, for a discussion of the resistance to, and possibilities of, design thinking in practice management. For similar discussions, see Jennifer Brown, "Law by Design" Canadian Lawyer (26 September 2016), online $<$ http://www.canadianlawyermag.com/6180/Law-by-design.html>; Brian Pike, "Design Thinking in a Future Legal Practice," Law Technology Today (28 July 2014), online: <http://www.lawtechnologytoday.org/2014/07/designthinking-in-a-future-legal-practice/>.

41 Abductive reasoning, as contrasted with deductive and inductive reasoning, is a cognitive process in which the only known is the value that we wish to create. The what and the how of achieving this value are unknown. The discovery, iteration, and re-iteration of these components - the what and the how - are the essence of design thinking. See section I.C below for a more detailed exploration of this concept.

42 Richard Buchanan, "Wicked Problems in Design Thinking" (1992) 8:2 Design Issues 5 at 5.

43 Ibid at 22. 
renowned Canadian designer Bruce Mau describes design succinctly as "the human capacity to plan and produce desired outcomes." 44 From this simple proposition stems an entire discipline that crosses professional boundaries and fields such as business, science, government, art, and engineering. To understand its universality is to come to grips with its innate applicability to virtually any creative human endeavour, including law.

Understanding design thinking and design processes holds promise in terms of understanding how we continually create and recreate. The things we design are not limited to physical objects but, rather, extend as far as our imaginations do into the abstract and the conceptual. Systems, ideas, and concepts exist primarily in our minds until we give them shape and form through words and human activity. And the conceptual "things" we create there are no less meaningful, necessary, effective, frustrating, or real than the "things" we live in, drive in, sit in, type on, or otherwise pick up and use every day. Money, law, commerce, scientific theory, poetry - they are all formless abstract ideas until we apply ourselves to their realization. How do we do this? Design practice and thinking attempt to describe a process by which we pull the hitherto unknown into the known and then improve on it and make it useful to our purposes. In satisfying both our needs and desires, design becomes "great" and ensures its own adoption, replication, scaling up, and evolution. ${ }^{45}$ It creates something we want to use as much as need to use.

This idea contrasts sharply with how law and legal systems are perceived - as opaque, clunky, slow, expensive, uncertain in utility, harsh in action, and punishing in outcome. ${ }^{46}$ To suggest that people should actually enjoy their interactions with legal systems, find them beneficial and useful, and be satisfied with the outcome (even when not all of their goals are met) might actually evoke humour or even derision. But to juxtapose these aspirations with the reality of the legal systems in which we do our work is to make the case for a new approach. What we are doing is not working. ${ }^{47}$ We need to create something different, and, to do that, we need to think about the problems differently. Fascination with the concept of design seems to me to be linked to a view of humankind as having capacity and agency in our world to shape things into useful, beautiful, or helpful objects, artefacts, and systems. The more we realize our capacity and agency, the more we seek to design the world around us. In this way, design as a concept is intimately linked to our self-conception as creative beings.

The disciplines that utilize and discuss design as a concept proceed along a continuum from science and engineering to the arts, embracing both the practical and the beautiful. At the same time, these disciplines conceptualize design along another spectrum from rational, constrained choices of solutions to

44 Warren Berger \& Bruce Mau, Glimmer: How Design Can Transform Your World (Toronto: Vintage Canada, 2009$)$ at 3.

45 Tim Brown, "Design Thinking," Harvard Business Review (June 2008) at 84, online: IDEO.com $<$ https://www.ideo.com/images/uploads/thoughts/IDEO_HBR_Design_Thinking.pdf $>$ [Brown, "Design Thinking"].

46 See, eg, Family Justice Working Group of the Action Committee on Access to Justice in Civil and Family Matters, Meaningful Change for Family Justice: Beyond Wise Words - The Final Report of the Family Justice Working Group (April 2013), online: <http://www.cfcjfcjc.org/sites/default/files/docs/2013/Report\%20of\%20the\%20Family\%20Law\%20WG\%20Meaningful\%20Change\%20April\%202013.pdf $>$; see also Action Committee on Access to Justice in Civil and Family Matters, supra note 1; Janet Mosher, "Grounding Access to Justice Theory and Practice in the Experiences of Women Abused by Their Intimate Partners" (2015) 32:2 Windsor Yearbook of Access to Justice 149, online: <https://ojs.uwindsor.ca/ojs/leddy/index.php/WYAJ/article/view/4688 >; Patricia Hughes, "Advancing Access to Justice through Generic Solutions: The Risk of Perpetuating Exclusion" (2013) 31 Windsor Yearbook of Access to Justice 1, online: <https://ojs.uwindsor.ca/ojs/leddy/index.php/WYAJ/article/view/4308>.

47 The Canadian Forum on Civil Justice's (CFCJ) recent report on everyday legal problems illustrates the extent to which the Canadian legal system is failing to meet the needs of users. For a full version of the report, see CFCJ, Everyday Legal Problems and the Cost of Justice in Canada: Overview Report (Toronto: CFCJ, 2016), online: <http://www.cfcjfcjc.org/sites/default/files//Everyday\%20Legal\%20Problems\%20and\%20the $\% 20$ Cost $\% 20$ of $\% 20 J u s t i c e \% 20 \mathrm{in} \% 20 \mathrm{Canad}$ a\%20-\%20Overview\%20Report.pdf $>$. This sentiment is also echoed in Action Committee on Access to Justice in Civil and Family Matters, supra note 1. 
open-ended, highly discretionary, and fluid processes where even the ultimate end for which design thinking is employed may be in flux. Surely, on either of these spectrums, there is room to find a concept of design that can be useful to law.

\section{But What Do Design and Design Thinking Mean?}

Design thinking, of course, is a "thought process." It is the cognitive activity that happens when we design. This process has been studied, its descriptions refined, and the results applied with the intention of improvement for decades. Design thinking has the attributes of being intentional, deliberate, and, despite its creativity, methodical and replicable. And, today, it is enjoying a period of recognition and appreciation that is perhaps unprecedented. ${ }^{48}$ Different thinkers who have contributed to our understanding of design thinking as an evolving discipline have conceived of the activity in different ways. Hagan, for example, conceives of design thinking as "the practice of making things that are useful, usable and engaging." Viewed in this way, Hagan sees design in terms of methods and outcomes as opposed to a particular subject matter. ${ }^{49}$ In a similar vein, Tim Brown, chief executive officer of the international design firm IDEO, describes the mission of design thinking as "translat[ing] observations into insights and insights into products and services that will improve lives." ${ }^{50}$ Nigel Cross, professor emeritus of Design Studies at the Open University in the United Kingdom, sees design thinking as a sort of ubiquitous activity that is "inherent within human cognition [and] a key part of what makes us human." ${ }^{51}$ Lucy Kimbell, associate fellow at the University of Oxford's Saïd Business School and associate at Normann Partners, which is a "design-oriented" international business consulting firm, has suggested in her review of several decades of research into design thinking that there are really three strands of "thinking about design thinking:" 52 design thinking as a cognitive style; design thinking as a "general theory" of design; and design thinking as a resource for organizations. ${ }^{53}$ While a consideration of the second of these three strands is beyond the scope of this article, it is useful to consider the implications that the first and last strands might have in the context of legal design.

\section{Design Thinking as a Cognitive Style: The Mindset of Abductive Reasoning}

Oddly enough, just as design thinking seems to be enjoying popularity across various disciplines, professions, and fields, some designers appear to be rejecting the concept as too woolly and vague to be useful. ${ }^{54}$ Academics and professionals have reacted to this by returning to a consideration of what exactly is happening cognitively in design thinking in order to re-evaluate the meaning, utility, and viability of the concept. Kimbell maintains that, while design thinking remains under-theorized and understudied, it is hardly a "failure" as described by other commentators. ${ }^{55}$ Instead, she believes that "the critical

48 For a concise and readable overview of the historic antecedents of design and design thinking, see Berger \& Mau, supra note 44, "The Briefing," particularly at 5-6.

49 Margaret Hagan, "Design Thinking and Law: A Perfect Match,” Law Practice Today (January 2014), online: American Bar Association https://www.americanbar.org/content/newsletter/publications/law_practice_today_home/lptarchives/2014/january14/design-thinking-and-law.html [Hagan, "Design Thinking and Law”].

50 Brown, "Design Thinking," supra note 45.

51 Nigel Cross, Design Thinking (London: Bloomsbury Academic, 2011), "Introduction."

52 Lucy Kimbell, "Rethinking Design Thinking: Part 1" (2011) 3:3 Design and Culture 285 [Kimbell, "Rethinking Design: Part 1"].

53 Lucy Kimbell, "Rethinking Design Thinking: Part II" (2012) 4:2 Design and Culture 129 at 141 [Kimbell, "Rethinking Design: Part 2"].

54 Johansson-Sköldberg, Woodilla \& Çetinkaya, supra note 19 at 121.

55 Kimbell, "Rethinking Design: Part 1," supra note 52 at 286. 
rethinking of design thinking has only just begun." ${ }^{, 56}$ Cross approaches this criticism of design thinking as too woolly and vague by breaking down assertions that designers rely too heavily on "intuition." He sees intuition not as irrational but, rather, as a response derived from "large pools of experience and prior learning." ${ }^{, 57}$ While Cross admits that design thinking is not based on conventional forms of logical inference, which scientists and engineers rely upon in their work, he sees an approach that recognizes the role of intuition as more useful to the work of what design thinkers do. ${ }^{58}$ Simply put, design thinking for Cross is a convenient form of abductive reasoning.

Roger Martin, renowned author and former dean of the Rotman School of Business at the University of Toronto, has observed that in business "[t]raditional firms utilize and reward the use of two kinds of logic: inductive - proving through observation that something actually works - and deductive - proving through reasoning from principles that something must be." 59 When it comes to design thinking, like Cross, he sees the process as based in abductive reasoning by virtue of its creative nature. ${ }^{60}$ Unlike Cross, however, Martin contends that inductive and deductive reasoning also play integral parts in the application of design theories, as part of the processes of iteration, testing, and re-iteration of potential designed solutions. In identifying abductive reasoning as the cognitive pattern at work in creativity and design thinking, theorists in design offer useful insights into the process of design thinking that should appeal to the legal community. They break down the seemingly "magical" creative properties of design thinking into carefully constructed models based on the language of logic. Such models are an attempt to re-situate design thinking as a knowable and replicable activity with clear attributes.

One such model is offered by Kees Dorst, a professor of design at the University of Technology in Sydney, Australia, and at the Eindhoven University of Technology in Eindhoven, Netherlands. In his article entitled "The Core of 'Design Thinking' and Its Application,", Dorst approaches two questions: "what is the core of design thinking" and "what could it bring to practitioners and organisations in other fields?" In answering these questions, he describes the fundamental reasoning pattern behind design: abductive reasoning. As part of his model, Dorst describes the basic reasoning patterns that humans use in problem solving, which are the "how," the "what," and the "result." In each form of reasoning, one or more components may not be known; thus, the form of reasoning "solves" the unknown component. Dorst explains that in deductive reasoning; the "what" and the "how" are known variables in the equation. For example, if we know there are stars in the sky (that is, the "what") and if we are aware of the natural laws that govern their movement (that is, the "how"), we can deduce where a star will be at a certain point in time (that is, the result). ${ }^{62}$

Dorst goes on to explain that with inductive reasoning, we know the "what" in the situation (that is, the stars) and we can observe the result (that is, the stars moving across the sky), but we do not know "the how" (that is, the laws that govern these movements). The proposal of "working principles" that could explain the observed behaviour (that is, the hypothesis) is a creative act. When it comes to scientific discovery, these hypotheses are subjected to critical experiments in order to falsify them. Therefore, as Dorst explains, "in the sciences, inductive reasoning informs 'discovery,' while deductive reasoning informs 'justification.' These two forms of analytical reasoning help us to predict and explain phenomena

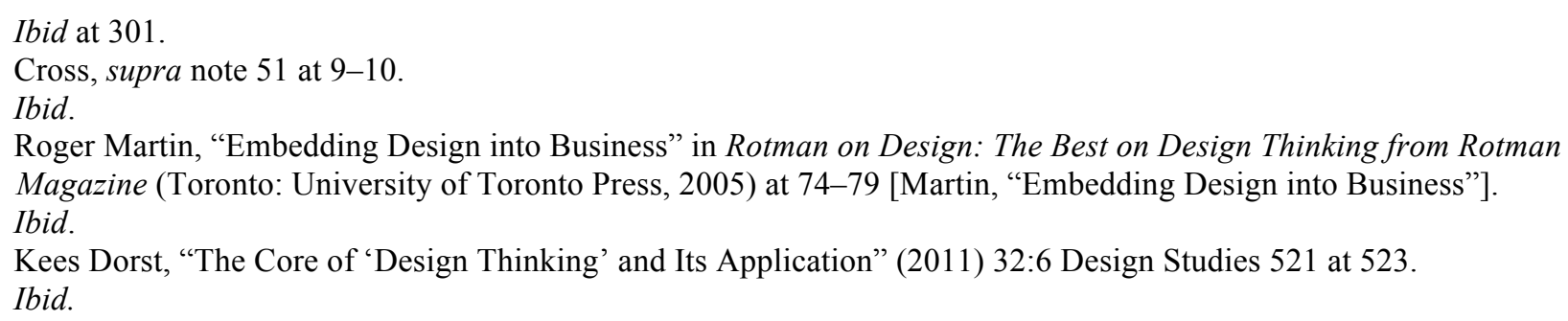


in the world." ${ }^{, 63}$ Finally, Dorst explains that abductive reasoning is a reasoning pattern with an importantly different component and another level of complexity. In abductive reasoning, we are no longer working with a "how," a "what," and a result; instead, we are looking for the "how" and the "what," which will lead to a "value." Dorst writes: "[I]f we want to create value for others, as in design and other productive professions ... [t]hen the equation changes subtly, in that the end now is not a statement of fact, but the attainment of a certain "value.",64

Design thinking uses the basic reasoning pattern of abduction, but Dorst further refines this pattern by breaking it into two forms: Abduction 1 and Abduction 2. What they have in common is that the outcome of the process is conceived of in terms of value. But they differ in the "unknowns" of the equation. With Abduction 1, we know the value we want to create (that is, the result) and the "working principle that will help achieve the value we aim for" (that is, the "how"). ${ }^{65}$ We are missing the "what." The "what" may be an object, a service, or a system, which will "give definition to both the problem and the potential solution space within which an answer can be sought." Abduction 1 is what we might associate with the type of conventional problem solving that designers and engineers do when they create within what Dorst calls a "set scenario of value creation." "67 But it is the other form of productive reasoning - Abduction 2 - that yields a better analytical framework within which to understand the work of designers when they engage in design thinking. Abduction 2 reasoning is almost immediately more complex because "at the start of the problem solving process we ONLY know the end value we want to achieve. This 'open' form of reasoning is more closely associated with (conceptual) design." "68 The challenge in Abduction 2, as Dorst writes, is to establish the identity of two unknowns - namely, to create both a "working principle" and a "thing" (object, service, system) in parallel. ${ }^{69}$

Designers respond to such challenges in a myriad of ways. Dorst suggests that students and novice designers may try to generate random matching proposals for the "what" and "how" that lead to the aspired value. ${ }^{70}$ More experienced designers, by contrast, bring more deliberate and efficient approaches to this work, utilizing certain knowledge, experience, and techniques to bear upon the problem. One such technique involves using a "frame" or particular working principle with which the problematic situation can be tackled. ${ }^{71}$ While abductive reasoning ultimately figures at the heart of the design-centred approach, it would be a mistake to think that design thinkers have abandoned inductive and deductive reasoning, analysis, or, for that matter, synthesis. They employ all of these cognitive techniques. This is evident in such models of design processes as the "double diamond" process (see Figure 1). The "double-diamond" pattern (literally, two diamonds side by side) is a visual representation of a design process that describes design phases as either diverging or converging. In a diverging phase, "you try to open up as much as possible without limiting yourself, whereas a converging phase focuses on condensing and narrowing your findings or ideas."72

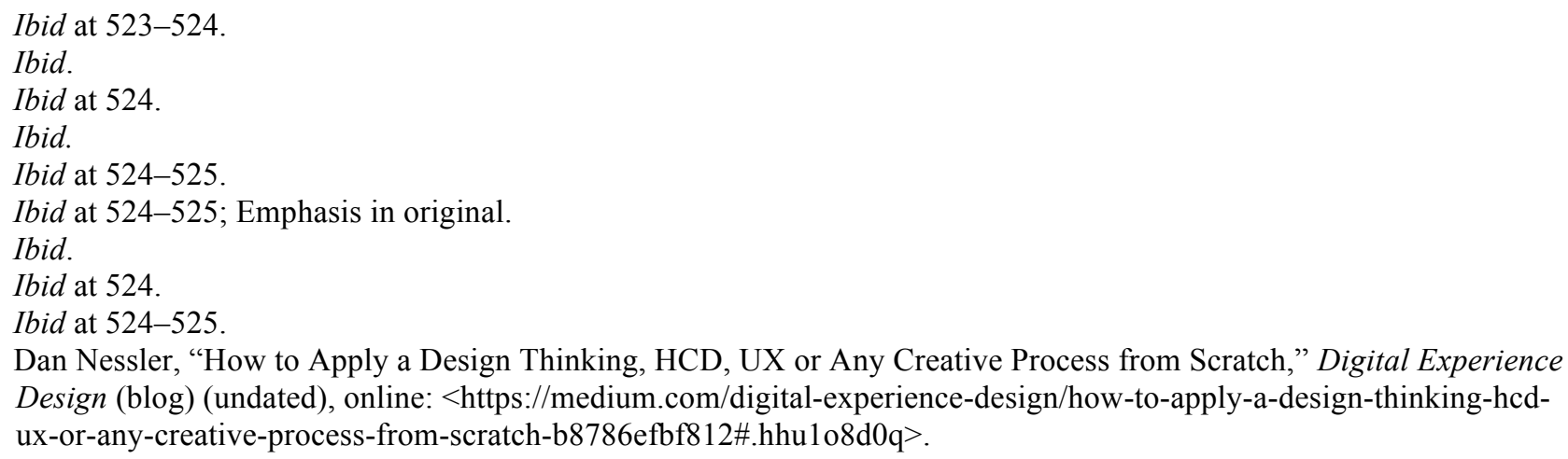


Once a problem has been set, the design team "diverges" or, as other writers describe it, have a "flare moment" in the initial discovery and research phase. ${ }^{73}$ Then, in the defining and synthesizing phase, designers "converge" by focusing on a particular area of the problem to solve. Next, in the development and ideation phase of looking at potential solutions, designers once again open up or diverge. Lastly, in the final phase of delivery and implementation, designers converge on solutions that work.

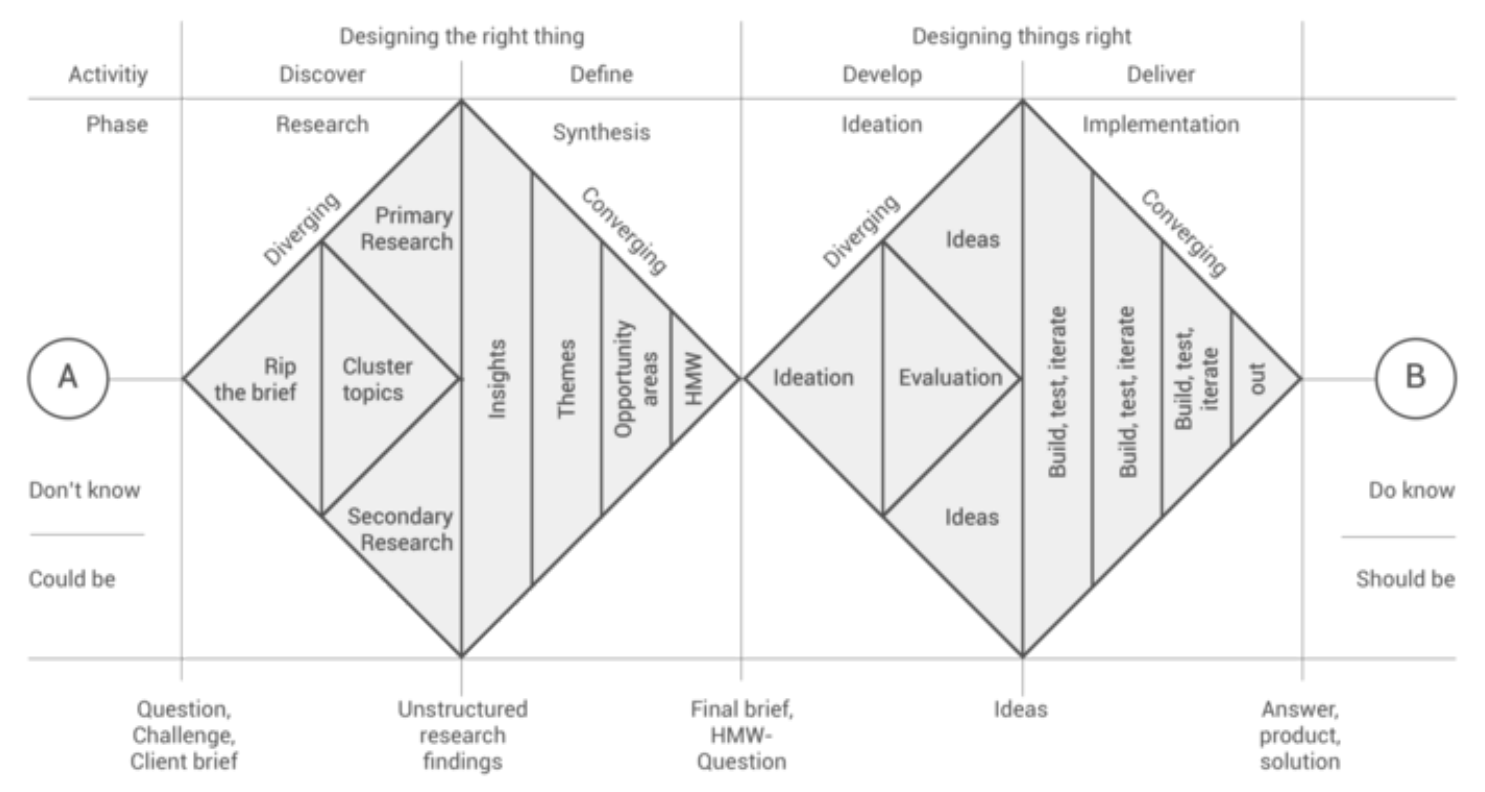

Figure 1: The Double Diamond Revamped

(taken from Dan Nessler, "How to Apply a Design Thinking, HCD, UX or Any Creative Process from Scratch," Digital Experience Design (blog), online: $<$ https://medium.com/digital-experience-design/howto-apply-a-design-thinking-hcd-ux-or-any-creative-process-from-scratch-b8786efbf812\#.hhu1o8d0q $>$ )

Throughout this model of a design process, all modes of thinking are engaged at one point or another:

- discovery/research: abductive, deductive, inductive, and analytic;

- define/synthesize: deductive, inductive, abductive, analytic, and synthetic;

- develop/ideation: abductive, analytic, and synthetic; and

- deliver/implementation: synthetic, analytic, and abductive if needed.

As the "bread and butter" of legal thinking, inductive and deductive reasoning deeply imbue key principles of law such as the rules of argumentation, evidence and proof, stare decisis, and precedent. Indeed, these forms of reasoning are the very fundamentals of common law traditions, which are intended to create certainty in both the path of reasoning and the result. Abductive reasoning, it could be said, is the polar opposite of such fundamentals. It contains within it speculation, hypothesizing, risk of failure of concept, and, most importantly, potential.

73 Hagan, "Design Thinking and Law," supra note 49. 


\section{Design Thinking as a Resource: Describing the Methodology}

Some theorists then have been preoccupied with the cognitive aspect of "design thinking." Others, like Richard Buchanan, have focused on a more methodological approach, describing the process of designerly thinking as a problem-solving technique in his foundational work "Wicked Problems in Design Thinking." 74 Tackling so-called wicked problems - "a class of social systems problems with a fundamental indeterminacy without a single solution and where much creativity is needed to find solutions," "75 Buchanan offers a set of tools called "placements": "Placements are tools by which the designer intuitively or deliberately shapes a design situation, identifying the views of all participants, the issues which concern them, and the invention that will serve as a working hypothesis for exploration and development."76 In a manner that prefigures Brown's methodologies, which are discussed next, Buchanan describes an iterative and re-iterative process, strongly based in an ethnographic approach to design, where "the problem formulation and solution go hand in hand, rather than as sequential steps.",77

Brown offers more user friendly methodologies, tools, and applications, which he presents as accessible and usable in a multiplicity of contexts. ${ }^{78}$ He sees "design thinking' as a methodology that can imbue innovation activities with a particular "human-centred design ethos." This ethos, according to Brown, dictates that products are made, packaged, marketed, sold, and supported with an understanding of what people actually want and need in their lives. ${ }^{79}$ Although he couches his definition in the language of the tangible and business world, Brown sees this idea as also applying to the intangibles of human existence that shape the quality of our lives. ${ }^{80}$ As Kees Dorst has noted, "[s]tudying the way designers work and adopting some designerly practices could be interesting to ... organisations [looking to broaden their repertoire of strategies for addressing the complex and open-ended challenges facing them] because designers have been dealing with open, complex problems for many years, and the designing disciplines have developed elaborate professional practices to do this. ${ }^{81}$

Descriptions of design thinking are more often focused on these "designerly practices" than on abstract "ways of thinking," although the latter are important windows into this work and should not be disregarded as we explore design's potential for law. ${ }^{82}$ On the other hand, descriptions of the processes used to engage in design thinking are far more accessible and, in the end, may also prove quite useful in broadening the repertoire of law's problem-solving skills. Rim Razzouk and Valerie Shute have canvassed the literature on design thinking in the context of education. Their working definition of design thinking approaches the discipline as a process, which begins with abstract specifications or requirements for an answer to a given problem that become gradually honed and defined through iteration and experimentation. As the process unfolds, the specifications may change in response to unanticipated problems until the final solution is reached. ${ }^{83}$

74 Buchanan, supra note 42 at 14-19.

75 Johansson-Sköldberg, Woodilla \& Çetinkaya, supra note 19 at 125.

76 Buchanan, supra note 42 at 17.

77 Johansson-Sköldberg, Woodilla \& Çetinkaya, supra note 19 at 125.

78 See IDEO, “Tools," online <https://www.ideo.com/tools $>$, for more applications developed by this design firm for use by lay people seeking to innovate and design solutions, particularly in a social context.

79 Brown, "Design Thinking," supra note 45.

80 See eg, "The New Social Contract: Or We're All in This Together" in Brown, Change by Design, supra note $26,177$.

81 Dorst, supra note 61 at 521-532.

82 For a helpful and more visual digest of designerly practices and techniques, see Katja Tschimmel, "Design Thinking as an Effective Toolkit for Innovation" (International Society for Professional Innovation Management Conference Proceedings, Manchester, 2012) at 1-20, online: <http://www.idmais.org/pubs/KatjaTschimmel/2012/actas_internacionais\%20c\%F3pia/2012.4.ISPIM.KatjaTschimmel1.pdf>.

83 Razzouk \& Shute, supra note 24 at 336. 
The parameters of this process, no matter who is describing it, seem to encompass some recurring themes. Brown describes the process as a "series of overlapping spaces rather than a sequence of orderly steps." ${ }^{84}$ More specifically, Brown describes these overlapping spaces or steps as follows: first, the inspiration phase, which encompasses the design brief containing the problem set and constraints within which the answer must be found; second, the ideation phase, which requires teams to develop their thinking around the constraints of the project and to prototype, test, iterate, and reiterate a designed solution to the problem; and, finally, the implementation phase, which is where the solution is actually implemented. ${ }^{85}$ As Brown notes, "projects will loop back through these spaces - particularly the first two - more than once as ideas are refined and new directions taken." As a result, he cautions that "[d]esign thinking can feel chaotic for those experiencing it for the first time." ${ }^{\prime \prime 6}$ That being said, designers are often willing to accept and even embrace the uncertainty of the design process, finding it both frustrating and joyful. ${ }^{87}$ Toleration for this chaos and messiness is a necessary component of the process, thus representing a particular challenge to the legal community, which is steeped in an orderly rules-based system of argumentation and persuasion. And, yet, even in law, there are apt analogies for this aspect of design. By participating and intervening in activities like corporate deal making, collective bargaining, insolvencies and restructuring, strategy development for complex litigation, or the process of creating rules for legal practice, lawyers routinely and willingly occupy this kind of messy and chaotic space.

Returning to the model of Abductive 2 reasoning, described above, we can see how an Abductive 2type reasoning describes this process. For Dorst, Abductive 2 reasoning requires developing an initial frame from which the designer can design a "thing" (object, system, or service) or working principle that will allow the equation to be completed. Until tested, however, the frame is merely a possible way forward that may or may not lead to the aspired value. ${ }^{88}$ Therefore, insofar as the designer may need to adjust and readjust her frame to achieve the aspired value that will fit within the equation, the Abductive 2 process can be quite messy, iterative, and even very frustrating at times. But as this design process moves through its stages and loops back from time to time, it manifests emergent properties - that is, properties that are "perceived, or recognized, in a partial solution or prior solutions, that were not consciously included or intended." 89 This feature of "emergence," which implies the possibility of redefining or refining the problem itself, is an aspect in design thinking that could prove challenging to the legal mind, accustomed as it is to dealing with set problems. At the same time, however, redefining and reframing client issues in order to find the appropriate solution is something lawyers do quite frequently. Being mindful and deliberate about applying this particular technique of reframing or framing, as Dorst describes it, is the added value of bringing design thinking to law.

There are many techniques and strategies used to evoke design thinking in individuals and teams. ${ }^{90}$ What follows is hardly an exhaustive list, but it provides a sense of the characteristics of design thinking

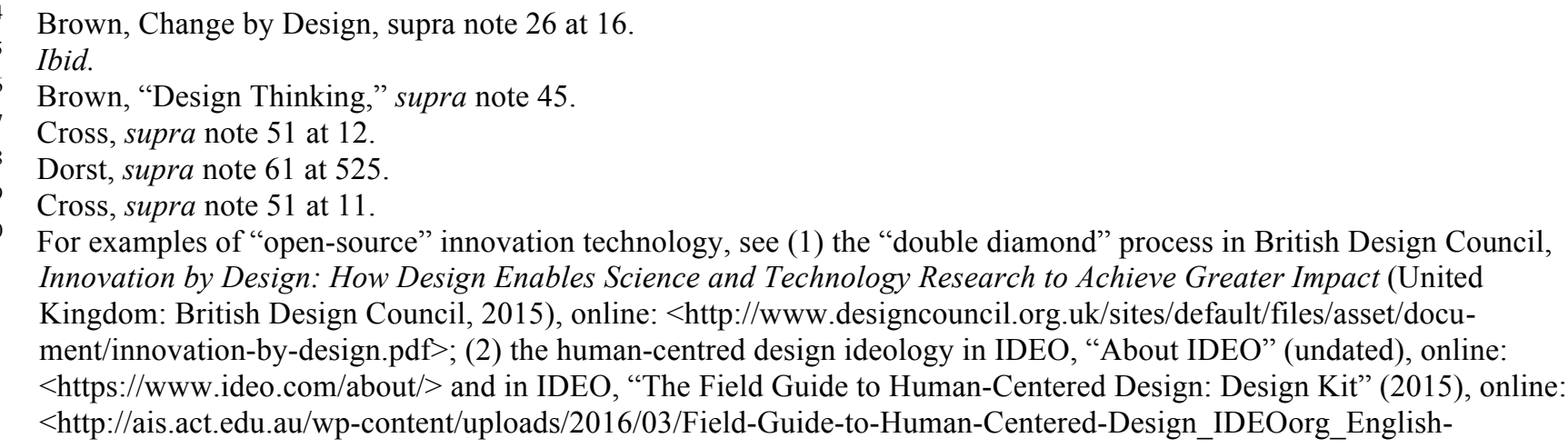


as it follows the methodology just described. In reviewing these descriptions, lawyers may also be struck by how familiar, similar, and/or adaptable many of these ideas are to how we approach problems in the practice of law. This adjacency to, and familiarity of, design thinking to legal thinking, while not without its challenges, is what can make it so translatable and useful to innovation in law.

\section{(a) Design Thinking Takes a Particular Stance towards the Question}

As we begin to grasp the nature of design thinking and its potential, it is only natural to wonder: what exactly does design thinking look like in action? The ways in which designers themselves think about their work can be, and often are, categorized into descriptions of design thinking, ${ }^{91}$ processes in design thinking, ${ }^{92}$ and individual designers engaged in design thinking. ${ }^{93}$ We will look at the latter two categories here in an effort to concretize some of the more abstract ideas about design thinking already considered.

What a designer does has both internal and external qualities. Some of the literature on design thinking has focused on identifying the personal characteristics of a design thinker. Often the literature attempts to distinguish between "expert" and "novice" designers by comparing either what they do or what they bring to the process of designing. In terms of this first component, "expertise" is often seen as both the result of dedicated application as well as the accumulation of examples of problems and solutions in a specific field of interest." Experts exhibit a key competency in being able to "stand back from the specifics of the accumulated examples and form more abstract conceptualizations related to their domain of expertise." 95 In other words, expert designers take a certain stance or perspective on the problem, derived from subject area knowledge. ${ }^{96}$ Charles Owen, a professor of design thinking at the Illinois Institute of Technology, has enumerated many examples of the "stances" or perspectives that different design experts have adopted, including a "human and environment-centric" stance that looks at how design responds to human needs; a "visualization" stance, which looks at how the graphic depiction of ideas can serve as an aid to design; a "systemic" stance, which sees problems as systems problems with holistic solutions; and so on. ${ }^{97}$

Heather Fraser, co-founder of Rotman DesignWorksTM and adjunct professor of business design at the Rotman School of Management, describes the attitude behind design as being comprised of three specific traits: open-minded collaboration, courage, and conviction. ${ }^{98}$ While less precise than Owen's descriptions, these are in fact the necessary psychological conditions, in my experience, for individuals and groups intending to use design thinking. Design thinking requires these traits because of the inherent uncertainty of the outcome and the experimental nature of the design process. These characteristics describe the mental stance design thinkers take towards their work. But how does that work manifest itself? What techniques do design thinkers use to handle complexity, generate multiple solutions, winnow out bad ideas, foster creativity, and situate possible answers appropriately to generate maximum results?

6b015db2a5cb79337de91e8f52a0ef03.pdf>; (3) the design-thinking process in d.school, "Our Point of View" (undated), online: <http://dschool.stanford.edu/our-point-of-view/>.

91

92

See section I.D.3 below.

93 For a readable introduction and overview of many of the techniques and strategies used by individual designers, see Marty Neumeier, The 46 Rules of Genius: An Innovators Guide to Creativity (Berkeley: New Riders, 2014), which is in turn a more accessible summary of that author's ideas in Metaskills: Five Talents for the Robotic Age (Berkeley: New Riders, 2012).

94 Razzouk \& Shute, supra note 24 at 338.

95 Ibid.

96 Recall in this discussion that designers and their work are often field specific - that is, they are architects, engineers, or computer systems designers and therefore accumulate such subject area expertise.

97 Adapted from Razzouk \& Shute, supra note 24 at 336.

98 Heather Fraser, “Turning Design Thinking into Design Doing” in Martin \& Christensen, supra note 25, 118. 
The answers to these kinds of questions lie in the techniques, as opposed to the mental stance, of design thinkers. The following small sampling of techniques gives a picture of designerly practices with an attempt to begin a dialogue about the usefulness of, and the points of resistance to, these ideas in law and among lawyers, as would-be legal designers. In anticipating that there will be questions about a designthinking approach, it is helpful to demonstrate where in law we might find we are already using these techniques and doing design thinking.

\section{(b) Design Thinking Is Visual}

Virtually every description of design thinking emphasizes the intensely visual, and sometimes tactile and physical, nature of design work. Mau calls it "making hope visible." 99 Brown describes it as "building to think," a process of moving from the physical to the abstract and back again as the fundamental way in which we "explore the universe, unlock our imaginations, and open our minds to new possibilities."100 The fact is that visualizations of ideas, thinking, concepts, tangibles, intangibles, systems, and the use of mind mapping, prototypes, and so on can actually help us think better about the problem we are solving. Designers draw because it clarifies their thoughts. ${ }^{101}$ Cross describes this need for an external visual representation in design work as deriving from certain internal cognitive limits that restrict how much information can be processed through the abstract. As Cross puts it, "sketching provides a temporary, external store for tentative ideas, and supports the 'dialogue' that the designer has between problem and solution."102

Not only do visual representations clarify the thoughts of the designer, but they also support dialogue between the designer and others, including the design team and client. As one designer put it, "the pencil is his spokesman." 103 Visualizations, whether artistic or not, convey information in a more cohesive, holistic, demonstrable, and non-linear way. A design thinker also uses visualization to engage abductive reasoning. As Razzouk and Shute note, "at its core, design thinking refers to how designers see and how they consequently think." 104 Design thinkers are intensely visual, even (or perhaps especially) when they are engaging with intangibles like services and ideas. The graphic visualization of a problem is what allows design thinkers to work out the myriad of details that comprise the solution. In describing the visual aspect of design work, Razzouk and Shute explain that design diagrams facilitate the designer's process of reflection, dialogue, and self-critique. By critically engaging with these processes, the designer is able to work towards solving the problem at hand. ${ }^{105}$

Lawyers intuitively know the value of a picture when they use demonstrative evidence in litigation, whether through pictures, videos, graphs, or charts. We already use visualization techniques in our work to facilitate understanding and persuasion; design thinking harnesses such techniques to facilitate thinking itself. Design thinkers who, like Hagan, are also lawyers are finding new ways to integrate visualization of problems and visual thinking into the practice of law, above and beyond the use of graphical aids in

99 Berger \& Mau, supra note 44 at 70-95. True confession, I borrowed this line for my opening statement when I was arguing in Batty $v$ City of Toronto, 2011 ONSC 6862, (2011) 108 O.R. (3d) 571 (Ont. Sup.Ct) (that is, the "Toronto Occupy" case). Now I have a chance to say thank you to Mau and to thank him for his precedent. See "Occupy Canada" (18 November 2011), online: Facebook < https://www.facebook.com/OccupyCanada/posts/336172839749160>.

100 Brown, Change by Design, supra note 26 at $87-108$.

101 Cross, supra note 51 at 12.

102 Ibid.

103 Ibid at 13.

104 Razzouk \& Shute, supra note 24 at 334-335 (Emphasis in original).

105 Ibid. 
litigation. ${ }^{106}$ In her blog about design thinking and law on the Open Law Lab website, she includes specific discussions of visualization as an aid to understanding and practising law as well as innovating in law. ${ }^{107}$

\section{(c) Design Thinking Is Social}

Large projects demand an important aspect of design ability, that of reconciling the varieties of interests - technical, financial, social, aesthetic, etc. - that inevitably have to coalesce around a major project. In these cases, designing becomes not just a personal cognitive process, but a shared social process. ${ }^{108}$

As Cross observes in the above quotation, design work is a fundamentally social process. Many aspects of design work make it social. First, design work usually assembles a team bringing multi-disciplinary or subject areas expertise as well as capacity. ${ }^{109}$ Certainly, some of the academic studies on design have focused on individual designers and what they do. But, for our purposes, the idea of a design team is probably the most analogous to how work is done in law and also how we might best employ design techniques to problem solve and innovate in law. Second, design is dependent upon a user-centric stance, which means that all things designed (both tangible and intangible) must be built with an understanding of the experience of the end-user. This makes design thinking social in another way. It requires deliberate engagement with end-users and other stakeholders. These so-called "deep dives" into the situation in which the problem exists, especially including the experience of people involved, have become emblematic of how designers work. Mau calls this "going deep" to figure out what people need. ${ }^{110}$

Brown speaks of the need for empathy in design in order to build what he labels as "bridges of empathy." 111 As connoted through this concept, he calls for an even deeper collaboration not just between team members but also between the team and the audience it is trying to reach. For Brown, the collaboration between users and team members is just one phase in the "evolution of design," which should ultimately strive to enable and empower people to "create by themselves through the application of user-generated content and open source innovation." "112 It is in what Brown calls the "middle space" of enhanced collaboration between creators and consumers where he sees the greatest opportunities of the moment. It is in this space that legal design thinking could also begin to transcend its profession-centric approach to problem solving by reaching out to end-users and other stakeholders. ${ }^{113}$ As lawyers, we need to actively and genuinely seek user participation in a design process that is intended to answer our clients' issues with the law, such as access to justice, self-representation, popular legal education or any other issue. Ultimately, if we are to make legal design work truly "social," we must embed it in the communities

106 For an overview of the use of graphical aids in litigation, see Ken Lopez, "Six Studies That Support Litigation Graphics in Courtroom Presentations" A2L Consulting (20 August 2012), online: <http://www.a2lc.com/blog/bid/58908/6Studies-That-Support-Litigation-Graphics-in-Courtroom-Presentations $>$.

107 See eg, Margaret Hagan, "Visual Law: Making Sense of the Legal System by Drawing It," Open Law Lab (11 February 2016), online: $<$ http://www.openlawlab.com/2016/02/11/making-sense-of-the-legal-system-by-drawing-it-e-g-turkishinternet-law $>$.

108 Cross, supra note 51 at 20.

109 Brown, Change by Design, supra note 26 at 26.

110 Berger \& Mau, supra note 44 at 99-125.

111 Brown, Change by Design, supra note 26 at 50.

112 Ibid at 58-59 (Emphasis in original).

113 I am referring here to the tendency of lawyers to think that only they can sufficiently appreciate the law so as to solve its associated problems. 
we seek to serve through projects, design challenges, labs, and other outreach efforts. In such an approach, design thinking could bring much to legal innovation.

\section{(d) Design Thinking Is Both Adversarial and Mediative}

Design thinking is constantly engaged in formulating and evaluating different and often opposing ideas or, what Owen calls, multi-functionality. And, at the same time, design, like law, is mediative in that, as Owen would put it, designers would rather avoid the necessity of singular choice and, instead, search for the solution that combines the best possible choices. ${ }^{114}$ Martin calls this capacity to synthesize ideas "integrative thinking" or "the ability to hold two opposing ideas in the mind at once, and then reach a synthesis that contains elements of both ideas but improves on each." ${ }^{115}$ Lawyers will recognize this description for its similarity to any worthwhile mediation process. Mediation, like design thinking, takes two (or more) opposing or differentiated sides and attempts, through discussion and argument, to arrive at a "synthesized" settlement. Now, in fact, while many lawyers will maintain that the surest sign of a good settlement is that everyone walks away just a little dissatisfied, the opposite is the real truth. In a good settlement, as with any good design, both sides walk away satisfied that their needs have been met to the extent possible within the constraints they are prepared to acknowledge and work with. In design, this is called "satisficing" or settling for what is good enough. ${ }^{116}$

In working with opposing ideas in a context of constraints, legal mediation is again very similar to design thinking. In law, we employ the best alternative to a negotiated agreement [or BATNA] theory to measure the satisfactoriness of a settlement by weighing it against the alternative, including measuring all of the viable possibilities and constraints of both the alternative and the settlement. ${ }^{117}$ In design thinking, we test prototypes for their viability and desirability as against the possibilities and constraints of the design project. ${ }^{118}$ These are two similar kinds of metrics for determining the satisfaction level with the proposed solution. What strategies can be used to trigger integrative thinking? The literature is full of these discussions. One simple methodology is to "change lenses," which involves looking at the problem from a different viewpoint. Another strategy is a "disruptive hypothesis," which is an "intentional unreasonable statement that gets your thinking flowing in a different direction." 119 Exploring dominant clichés or beliefs about a subject and then inverting or denying them is a method for generating "disruptive hypotheses." Of course, this method has much in common with adversarial modes of argument.

The "disruptive hypothesis" method should be familiar territory for any litigation lawyer who must "change the lens" and understand the opposing counsel's case at least as well as her own if she is to be an effective advocate. As a means of assessing litigation risk and the potential for other remedies, a litigation lawyer must hold competing viewpoints in tension. The design-thinking process takes this exercise one

114 Charles Owen, "Design Thinking: Notes on Its Nature and Use" (2007) 2:1 Design Research Quarterly 16.

115 Berger \& Mau, supra note 34 at 304, quoting Roger Martin; see also Roger Martin, The Opposable Mind (Boston: Harvard Business Review Press, 2009).

116 Berger \& Mau, supra note 34 at 217.

117 The "best alternative to a negotiated agreement" theory asks the question "what's the best you can do if the other person will not negotiate with you?" See Roger Fisher \& William Ury, Getting to Yes: Negotiating without Giving In (New York: Penguin Books, 2011).

118 Mau and Berger define the term "constraints" in design as "the limitations, restrictions, and requirement inherent in a particular design challenge." For Mau and Berger, these constraints provide the necessary structure within which the thinking - legal or design - goes on. See Berger \& Mau, supra note 44 at 215.

119 Luke Williams, Disrupt, quoted in William D Eggers \& Paul MacMillan, The Solution Revolution: How Business, Government and Social Enterprises Are Teaming Up to Solve Society's Toughest Problems (Boston: Harvard Business Review Press, 2013) at 206. 
step further by actually letting go of the original problem and desired outcome in favour of different problems and outcomes that may actually provide a better solution to the original issue.

\section{(e) Design Thinking Uses Metaphor}

Metaphor is one of the most powerful tools for both problem solving and persuasion that we have. An apt metaphor can capture the imagination, open people up to seeing things in a new way, sweep aside preexisting biases, and enable a kind of empathic resonance that makes human society possible. Indeed, it may be the only tool by which we can grasp and understand some things. It is not surprising then to find that metaphor is an important aspect in both law ${ }^{120}$ and design. Metaphor in law, for example, is what makes the system of precedent so effective. It allows us to translate legal principles across subject area boundaries, disciplines, and even entire fields of human behaviour. It allows us to discern, however imperfectly at times, the underlying principles with which we intend to order our lives and societies. Sometimes those principles are deeply culturally specific, yet metaphor enables us to see where they may transcend specific cultures in pointing to a deeper form of shared human experience. Metaphor in law is what can make law humane.

In her essay entitled "Metaphor in Law as Poetic and Propositional Language," Linda B. Berger, associate dean for faculty development research in the William S. Boyd School of Law at the University of Nevada, Los Vegas, talks about how metaphors can push lawyers to transcend their individual biases. Pointing out the tendency of lawyers to distrust intuition and imagination, Berger argues that a scrupulous adherence to rational modes of thought and discussion may simply perpetuate biases. As a means of counteracting such biases, she calls on lawyers to "harness the power of imagination" in favour of adopting more intuitive means of thought. ${ }^{121}$ Metaphor in design is similarly important but far more deliberately employed. Mau calls it, among other things, "jumping the fence" - that is, taking ideas from seemingly unrelated fields and importing them into the problem/solution matrix in a particular piece of design work. ${ }^{122}$ By using abductive reasoning and "jumping fences" through metaphor and "asking stupid questions," designers are able to "glimpse possibilities that lie on the other side of the fence." 123 In order to use metaphorical thinking, however, Mau says that designers need to be given room to transcend habit, convention, and even disciplinary boundaries in favour of "free range thinking." 124

And it is in this use of metaphor - of "jumping fences" and "free ranging" - that design thinking offers a significant challenge to those in law who would use design thinking to advance innovation. For despite our familiarity with metaphor as a rhetorical device by which to understand law, legal theory, and legal systems, we still find it difficult to subdue our critical faculties. Too often, schooled in our adversarial techniques, we strangle the idea in the cradle rather than letting it grow and develop. Mau's approach, however, pushes against this professional bias, calling for cross-disciplinary teams and deep dives into the experience of the end user. ${ }^{125}$ In this example of how to move past "conventional wisdom" into the zone of "original and startling insights," we can also see the interrelated and mutually supporting nature of many of the techniques used by designers. Trying to employ metaphor without the social constrains the field of available metaphors. Using the social without the visual hampers the ability of a design team to

120 See eg, Finn Makela, "Metaphors and Models in Legal Theory" (2011) 52 Les Cahiers de Droit 397.

121 Linda L Berger, "Metaphor in Law as Poetic and Propositional Language," Scholarly Works Paper 749 (2013), online: William S Boyd School of Law <http://scholars.law.unlv.edu/facpub/749>, quoting Elizabeth Camp, "Two Varieties of Literary Imagination: Metaphor, Fiction, and Thought Experiments" (2009) 33 Midwest Studies in Philosophy 107.

123 Ibid at 46.

124 Ibid at 50.

125 Ibid at 54. 
communicate both the problem set and the solution to those who could help. Using the visual without the adversarial and mediative risks drowning the design work in excessive detail. These techniques provide balance as well as a way to move through a design problem, following, for example, the "double-diamond" model and giving us ways to implement such a process.

\section{(f) Design Thinking Works with Systems}

Systems and systems theory are major disciplines in their own right, and it is certainly beyond the scope of this article to fully explore what systems theory might offer law. That being said, it is an undeniable fact of design thinking that it engages with, thinks in, and seeks to change "systems." In defining what it is we mean by "systems theory," Donella Meadows, a pioneering American environmental scientist, teacher, and author, offers a helpful way into seeing systems. She describes systems as "a set of things people, cells, molecules, or whatever - interconnected in such a way that they produce their own pattern of behaviour over time." 126 But more than viewing a system as a mere "collection of things," what defines systems for Meadows is the fact that they contain three distinct things: elements, interconnections, and a function or purpose. ${ }^{127}$

Meadows goes on to consider both how systems are self-sustaining, self-replicating, and how they operate internally and in conjunction with other systems. Furthermore, she goes on to describe the implications of a systems view of the world, which seems to alleviate individual responsibility, at least in part, where certain events occur. She explains, for example, that "[d]rug addiction is not the failing of an individual and no one person ... It is only through understanding addiction as part of a larger set of influences and social issues that one can begin to address it." ${ }^{128}$ Designers understand this implication. They know that it is important to understand the system they are engaging in any design project because they are ultimately seeking to change it in order to obtain a different and better result. In the process, they may become embroiled in trying to understand and work with other systems, or sub-systems, and they need to understand how those systems work as well because systems, in their complexity and adaptiveness, affect each other. $^{129}$

To see how this is so, we need only think of how government systems - legislative, executive, and administrative - directly impact legal systems like courts and adjudicative services or law firms and other service providers. We know these two "systems," government and legal, are not the same system, but we can also see, to use Niklas Luhmann's language, that they are closely structurally coupled and, indeed, are dependent on being structurally coupled for their own operation. No self-respecting lawyer, however, would mistake the government's legislative function for the court system's jurisprudential function. In other words, while both systems may be "structurally coupled," they also exist as systems unto themselves,

126 There is perhaps no better grounding in systems theory than the seminal book by Donella $\mathrm{H}$ Meadows, Thinking in Systems: A Primer (White River Junction, VT: Chelsea Green Publishing, 2008). For a helpful introductory overview on systems theory and law, see Lynn M LoPucki, "The Systems Approach to Law" (1996-1997) 83 Cornell L Rev 479. For an approachable introduction to Niklas Luhmann's social systems theory, see Hans Georg Moeller, Luhmann Explained: From Souls to Systems (Chicago: Open Court, 2006). For a more developed appreciation of the "lens" of systems theory as applied to law, see Richard Nobles \& David Schiff, Observing Law Through Systems Theory (Oxford: Hart Publishing, 2013).

127 Meadows, supra note 126 at 2.

128 Ibid at 2.

129 Complexity theory is another field related to systems theory and, again, well beyond the scope of this article to explore. For a useful discussion of complexity theory and its practical applications, see Plexus Institute, online: $<$ http://www.plexusinstitute.org $>$; see also Tamarack Community, "Complexity: A Conversation with Brenda Zimmerman" (undated), online: $<$ https://www.outcomemapping.ca/download/simonhearn_en_Complexity_a_conversation_with_Brenda_Zimmerman_2005_155.doc>. 
with "operational closure," which makes it possible to see their boundaries and to see what makes each a "system." " Designers apply a "systems lens" to their design problem when they engage in visualization, social research, metaphoric thinking, and other techniques previously discussed in this article. They work directly with understanding the system, looking for those leverage and tipping points where a system can be moved to change, without necessarily doing away with what might be a very necessary system in other respects in the process.

Lawyers do this too, for example, when we assess a case for its potential as a precedent-setting piece of litigation. We are assessing the factual matrix or factual system of the case, as well as the legal and other governance systems that the facts operate within, to see if there is potential to change some aspect of those systems through the operation of law (perhaps jurisprudentially, perhaps legislatively, perhaps through regulation) to achieve the best result for our client. In the best kind of "precedent-setting case," we actually influence the larger meta-systems, including society itself, to move towards a better result and a better way of seeing the issues in the litigation. ${ }^{131}$ It is through the use of this lens of systems thinking that design thinking also demonstrates its utility for, and affinity with, the field of social innovation, which itself is very often concerned with the delivery of services. Social innovation is engaged with social systems and is concerned with novel solutions to social issues. To do so, it starts with a view of the systems it is trying to influence. ${ }^{132}$ In engaging with social systems, in bringing a systems view to the work, and in bringing a design approach to its projects, social innovation then represents a form or application of design thinking in action, which also could have fruitful application in law.

\section{B. Why Law is Like Design Thinking}

When reading Warren Berger and Bruce Mau's Glimmer: How Design Can Transform Your World, I was struck by the similarities between what designers do and what lawyers do. ${ }^{133}$ Drawing on the work of George Kembel, co-founder of Stanford University's d.school, Berger and Mau extrapolate from Mau's own streamlined design process (questioning standard processes, engaging in experimental thinking, creating sketches, prototypes, and representations of ideas, and bringing in empathic research) to provide an overview of the design process in their book. Kembel acknowledges that there may be any given number of steps in a design process. He conceptualizes any design process as having five basic requirements (not necessarily in a particular order): (1) gaining expertise about a problem or subject area, primarily through empathy with the people directly involved; (2) framing the challenge you are going to tackle; (3) generating options or ideas; (4) creating prototypes to test those options; and (5) iterating, or creating, subsequent refined versions of your original prototype based upon feedback. ${ }^{134}$

This description of the design process in fact sounds very much like what lawyers do. We gain expertise in a subject area, law, or subspecialty of law (often through interaction with clients) and then apply that

130 Hans Georg Moeller, "What Is Social Systems Theory?” in Moeller, supra note 126.

131 For a small example of this kind of systems thinking in law, I can turn to my own experience in XY v Ontario, 2012 HRTO 726 (CanLII). The case involved a human rights challenge to a requirement under the Vital Statistics Act that a transgendered person have surgery before the sex designation on the birth certificate could be changed. The compelling fact of the case was that in having the surgery in order to change a letter on a document, the litigant deprived herself of the ability to procreate in order to resolve the problem of having identification documents that conformed with her gender identity. The sensitive nature of this case and its facts ultimately offered a successful entry point into changing the system around sex designation on birth certificates by removing the surgical requirement. In the process, the case moved forward the jurisprudence, regulatory practices, and general social understanding on transgender rights. Frances Westley, “The Social Innovation Dynamic” (2008) SiG@Waterloo, online: <http://www.sosyalinovasyonmerkezi.com.tr/yayin/1020080009.pdf>.

133 Berger \& Mau, supra note 44 at 272.

134 Ibid. 
to a problem brought to us by our client. We develop an empathic understanding of the issues that face our clients. We frame our clients' challenges within pre-existing legal structures where possible and use broader contexts where the challenges cannot fit within existing frames. We generate options and ideas through research, investigation, interviewing, and examining the evidence or the precedents that created the problem in the first place. We create prototypes to test those options in the form of legal arguments, facts, contracts, legislation, and regulations. Finally, we iterate, refine, and redevelop our prototypes based on feedback from clients, opposing counsel, judges and decision makers, other stakeholders, our colleagues, and other professionals whose work integrates with ours.

\section{But Design Thinking is Also Very Challenging to the Legal Mindset}

If design thinking is so integral to what we do as lawyers, then why do we not see ourselves as designers doing creative work? I want to suggest that part of the problem stems from the very nature of the system of law that we work within. Law as a system must be able to encompass and order other systems, like financial systems, governmental systems, health care systems, education systems, policing systems, and dispute resolution systems. Ordering other systems is law's function, and while theorists may debate this, I would argue that law's primary function is to provide meta-ordering principles for other human activity in order to enable society's functioning. ${ }^{135}$ Of course, this purpose is enormous and has profound implications for how we understand what we do.

Given its purpose and tasks, law as a system must be incredibly resilient but not necessarily wildly creative. It cannot be too flexible as to lack ordering principles or rules, yet it cannot be overly rigid as to risk collapsing in the face of change. In order to strike this intricate balance, law has developed tools for achieving flexibility without chaos. These tools come in the form of principles like stare decisis, which preserve the integrity of the law yet contain within themselves a capacity for (more or less) orderly legal change through democratic institutions like governments, legislatures, and courts. Law, as a system, strives to provide some certainty within which other human activities take place. In this, it is averse to risk and can literally punish those who engage in careless risks. ${ }^{136}$ These structures, and others like them, shape and inform our "legal mindset."

What does all of this mean for the idea of design in law? Design is, in my view, undeniably a part of the activity of law. But theories and practices of design thinking represent a challenge to the legal mindset insofar as they suggest that deep, even fundamental, change at a systems level should sometimes be preferred over incremental change when working with intractable problems. As Mau would describe it, sometimes designers have to "jump the fence" by connecting, reinventing, and recombining the ideas with which they work. ${ }^{137}$ If law is the "fence," then jumping the fence requires us to literally and figuratively think outside law as it is, to law as it might be. Hagan, in particular, identifies five "mindsets" associated with design thinking that she believes are counterintuitive to the way that lawyers think. These "mindsets" are as follows: (1) centring the design work on the user rather than on a legal problem or issue; (2) structuring the process to solve the user's problem rather than simply answering a legal question; (3) favouring concrete action over simply thinking or talking through a problem; (4) using feedback from

135 Legal theorists Eugen Ehrlich and Santi Romano conceive of law as a "meta-institution" whose purpose is to govern, organize, and order other institutions. On the other hand, Sally Falk Moore conceives of law as one "semi-autonomous social field" that simply exists among other fields. For a full explanation of these legal theories and how they diverge from one another, see Mariano Croce, Self-Sufficiency of Law: A Critical-Institutional Theory of Social Order (Rome: Springer, 2012) at 71-83.

136 For an informal discussion of these kinds of impediments to innovation in law, see CBA Futures, "If At First You Don't Succeed ..." Slaw (7 November 2013), online: <http://www.slaw.ca/2013/11/07/if-at-first-you-dont-succeed/>.

137 Berger \& Mau, supra note 44 at 45-69. 
end-users as part of an iterative approach to developing a solution; and (5) using an inter-disciplinary team approach. While these mindsets may be particularly challenging for lawyers to adopt, they ultimately describe the best working practices for achieving lasting legal innovation. ${ }^{138}$

Design is also a challenge to a legal mindset in the sense that it requires its proponents to reside in the space of uncertainty and potentiality, whereas law wants certainty and definitiveness. Law most commonly employs deductive and inductive reasoning, while design employs abductive reasoning, although if we were honest with ourselves, we would acknowledge that many of the legal problems our clients bring us share far more in common with abductive reasoning than these other forms - that is to say, the only certainty is the value that is desired to be achieved, leaving the how and the what to be created by the lawyer. ${ }^{139}$ Couple these innate tendencies to avoid risk in the system of law with the consequences of being wrong that are borne by lawyers (that is, being perceived as or found to be negligent or careless), and we have a wall of resistance to design thinking that has as its foundational characteristics creativity, novelty, risk, uncertainty, potentiality, emergence, and originality. All of these cultural and professional practices lead to a mindset in law that is notoriously unwilling to venture into what is believed to be unknown territory. The CBA even recognized this mindset explicitly in its Futures report when it observed: "The legal profession to date has been, in large part, conservative in dealing with change ... [and] can no longer afford to plan for the future on an occasional basis." 140

Fortunately, though, we are not the first profession to have ventured into this design territory in search of new answers to ever more intractable questions. Engineering, business, medicine, finance, and the nonprofit sector have all been here ahead of us. And all have faced issues of interest in, acceptability of, and willingness to engage with design and innovation. ${ }^{141}$ Despite their initial hesitations, all of these disciplines have, to an extent, opened themselves up to learning more about the processes, techniques, and strategies that promise solutions to their intractable problems. The literature on design and innovation in these fields is replete with examples and case studies of successes and failures from which learning can occur. ${ }^{142}$ What is clear, however, is that in these fields there is a large and ongoing attempt to use design

138 Hagan, "Design Thinking and Law," supra note 49.

139 We need only think of the work involved in drafting a contract to understand how abductive reasoning is employed on a daily basis by lawyers. The client knows the value they wish to achieve - the how and what of it are part of the design the lawyer creates. Tensions do arise between the client's desired outcome, the available legal options at any particular time, and the assessment of risk in innovating. But this is precisely where law as an art, not just as a technical field, becomes apparent.

140 CBA Legal Futures Initiative, supra note 12 at 4.

141 For one example from a discipline that we would not assume has a problem with design, see Razzouk \& Shute supra note 24 at 330-331, on how the field of engineering grappled with design training almost two decades ago.

142 See eg, Christian Seelos \& Johanna Mair, "When Innovation Goes Wrong," Stanford Social Innovation Review (Fall 2016), online $<\mathrm{https}$ //ssir.org/articles/entry/when_innovation_goes_wrong >; Cheryl Heller, "Designing a Way to Measure the Impact of Design," Stanford Social Innovation Review (9 March 2017), online

$<$ https://ssir.org/articles/entry/designing_a_way_to_measure_the_impact_of_design>; Piyush Tantia, "The New Science of Designing for Humans" (2017) 15:2 Stanford Social Innovation Review 28; see also Martin \& Christensen, supra note 25, for a series of essays on this topic. The website "This Is Design Thinking," online: <http://thisisdesignthinking.net/category/cases/ $>$ is specifically dedicated to examining design thinking adoption in organizations. It provides contemporary examples of design thinking across disciplines, professions, fields, and domains. Another rich source is the Harvard Business Review and its various imprints. Eg, the September 2015 issue contained feature articles under the heading “The Evolution of Design Thinking." As well, Harvard Business Review's "Case Study" series of papers includes a number of case studies on design thinking, including the classic "Design Thinking and Innovation at Apple" by Stefan Thomke and Barbara Feinberg (2009). See also, eg, Dirk Deichmann \& Roel van der Heijde, "How Design Thinking Turned One Hospital into a Bright and Comforting Place," Harvard Business Review (2 December 2016), online <https://hbr.org/2016/12/how-design-thinking-turned-one-hospital-into-a-bright-and-comforting-place>; 
principles in an organized and intentional way to achieve concrete and meaningful results. According to Martin, firms must embed and not simply append design principles into their business models in order to reap the full benefits of design. ${ }^{143}$ As a means of accomplishing this embedment, Martin suggests that businesses need to address key differences in five key dimensions: flow of work life; style of work; mode of thinking; source of status; and dominant attitude. "Left unchecked," he argues, "the stark contrast between traditional firms and design shops on these attributes will impede any attempt by traditional firms to become more 'design-oriented'.,"144

Martin describes the difference between the two settings along various axes. First, while firms engage in work that is permanent and ongoing, design shops engage in project-based work that is episodic and time limited. Second, while firms structure their jobs and hierarchies along rigidly defined lines with laid out individual responsibilities, design shops feature more collaboration, iteration, and experimentation. Third, while the mode of thinking in traditional business, as in law, is deductive and inductive, in design it is abductive. Fourth, while the source of status in business is management of large budgets and staff, in design, "[t]he source of status and pride ... derives from solving 'wicked problems' - problems with no definitive formulation or solution, whose definition is open to multiple interpretations." 145 Finally, while the dominant attitude in business, according to Martin, is to see budgets and constraints as inhibitory, in design, these things are viewed as positive in the sense that they validate the worthiness of the wicked problem.

In describing the difficulties of bringing design thinking into the business world, Martin illustrates how design and law, by contrast, may actually mesh far better than we could have anticipated and perhaps better than design and business. He explains that while in traditional firms the flow of work life is organized around permanent jobs and ongoing tasks (for example, managing an advertising plan, setting a marketing budget, coordinating with sales, and so on), in design shops, the work flow consists of projects of fixed duration with defined terms. This is more similar to the work of law firms, with our individual briefs for clients with fixed time frames, goals, and outcomes. As Martin frames it, "[designers] view their careers as an accumulation of projects, rather than a progression of hierarchical job titles - i.e. manager, director, AVP, VP SVP, EVP, and CEO."146 Similarly, lawyers view their careers as an accumulation of cases. As for a progression of job titles, the hierarchy in law is rather flattened as compared to business student, associate, partner; the progress is measured not in job titles but in undertaking increasingly complex work or projects.

While, in Martin's analysis, there are inherent challenges in the introduction and use of design thinking, I would hope that it is more than obvious that law shares a great many similarities with design thinking and design work. It is in these similarities that we can find the case for an affinity between law and design,

Robert I Sutton \& David Hoyt, “Better Service Faster: A Design Thinking Case Study," Harvard Business Review (6 January 2016), online: <https://hbr.org/2016/01/better-service-faster-a-design-thinking-case-study>. Entrepreneurs are also entering the design thinking and innovation space with products and services. While design firms like IDEO have established reputations and track records, newer entities also provide insights into this field. See, eg, WE THINQ, innovation software developers whose website and blog feature their own work as well as case studies from a variety of industries. Kayla Kurin, "How to Solve Complex Problems with Design Thinking (with Case Studies)," WE THINQ Blog: A Space for Change Makers (15 March 2016), online: <https://www.wethinq.com/en/blog/2016/03/15/Designthinking-for-big-problems.html>.

143 Martin, "Embedding Design into Business," supra note 59 at 74-79.

144 Ibid.

145 Ibid. It is perhaps an apt analogy for the adversarial system of law to describe it in terms of a design competition: a neutral third party must adjudicate between two or more competing views on a problem that is essentially "wicked" in nature (that is, can be interpreted in multiple ways). Viewed in this way, the practice of law is design in action.

146 Ibid 
which could be fruitful and useful. Given the similarities in the flow of work life, style of work, source of status, and dominant attitude, it may not be such a leap to import the additional methods of design thinking and the practices that go with them into legal practice and, by extension, into the field of law itself. Design thinking fits into law because this is how we work in law.

\section{What Design Thinking Can Offer Law}

Design thinking is fundamental to innovation. And design thinking could bring something important to law in its own right. The possibility of a legal design discipline is very exciting and could impact the work of law in all of its manifestations: education; law-making; working with and in law; law firms; legal services; institutional design; and legal theorizing. If we think of law and work in law as a design project, we may open up new ways of thinking about, creating, and implementing solutions. Contending that "law is ripe for design thinking," Hagan explicitly recognizes the potential for design thinking to improve the organizational culture of law and its product and service deliveries. ${ }^{147}$ The idea that law might have its own "design thinking" discipline is also in line with views expressed by Kimbell. She conceives of design thinking and design practice as deeply embedded in the culture in which this work occurs. She sees the need to link the designers with the end-users and other stakeholders as well as the materials, objects, systems, and processes involved, all of which make possible particular and specific design practices or "ways of doing, knowing and saying." 148 In this sense, she articulates a view of design thinking that is situated within a particular context for a particular purpose.

It is equally important to view designing and design thinking not as isolated activities of professionals but, rather, as processes that happen within a matrix of people, things, structures, processes, systems, knowledge, discourse, and agency. In other words, they should be viewed as thoroughly "social processes." 149 This view conceives of design as having multiple facets: a rational problem-solving activity, a process of creating meaning, a process concerned with generating new ideas, and a process that interacts and is affected by other processes. In the business context, this "matrix of people" refers to managers, employees, customers, end-users, and those "who through their [own] practices [of using the designed thing] also take part in design[ing it]. ${ }^{150}$ What is important about the broader vision that Kimbell brings to theorizing about design thinking is that it recognizes the situation-specific nature of most design thinking and work. This is a useful view to bring to the idea of legal design thinking because it acknowledges the unique milieu in which such work would be done. While general models or processes can (and probably should) provide us with a starting place for design thinking in law, we should not limit ourselves to them. As legal problems become more complex, general design models can also evolve into more sophisticated and nuanced ones.

Of course, it would be premature to suggest that there exists a legal design thinking discipline, but the possibility for it is both exciting and daunting. Hagan, among others, has begun the work of introducing design thinking as part of the discipline of legal thinking and is writing about how it can be utilized; such initiatives are necessary in order to provide a basis for further development of this potential discipline. ${ }^{151}$ Another natural starting place for creating such a discipline would be in the education of future lawyers. While a grounding in the substantive law is an obvious aspect of legal education, perhaps more important is the instilling of a legal mindset. This fundamental grounding - indeed, one could almost say

\footnotetext{
147 Hagan, "Design Thinking and Law," supra note 49.

148 Kimbell, "Rethinking Design: Part 2," supra note 53 at 130.

149 Ibid at 135.

150 Ibid.

151 Margaret Hagan, “Law by Design” (2017), online: <http://www.lawbydesign.co/en/home/>.
} 
indoctrination $^{152}$ - into the tools of legal thinking includes understanding the building blocks of legal decision making (facts, issues, holding, reasoning); the principles of the common law; the basic components of legal argumentation both oral and written; the concept and rules of evidence-based decision making; ethical and moral considerations and their interplay in the historical division between law and equity; and so on. Because law school is at its core concerned with instilling the proper capacity to participate in the profession by teaching how to think as a lawyer, it creates the opportunity, space, and reason to offer a broader repertoire of thinking skills, like design thinking, which can be deployed in the practice of law.

But beyond these profession-specific reasons that law schools are a natural home for design thinking are the broader social reasons for incorporating techniques like design thinking and innovation - both social and entrepreneurial - into the legal academy. As Marta Urquilla notes in her essay "To Build Leaders for Social Impact, Universities Must Adapt":

Students seeking social impact careers often regard business schools as the go-to source for learning opportunities. But while business schools can help these students develop many important skills and ultimately work toward the triple bottom-line of profits, people, and the planet, it's important that universities extend social impact education into other disciplines. The world needs a variety of leaders, with a range of expertise, committed to the public good in every sector - and universities, as multidisciplinary environments, are uniquely positioned to produce such talent ... [but] universities need to take a broader approach to social impact education, while also making it accessible and inclusive. ${ }^{153}$

Describing universities as "platforms for the future," she expressly calls for "social impact education" in the development of skills and talents for creating meaningful, necessary social change. Drawing on the history and tradition of the academy, she argues that universities hold a special place in this work that is not replicated anywhere else in society:

Universities remain important to shaping the future and building a more just world. But they must adapt to provide social impact education, and seek to apply new modalities of teaching and learning to engage diverse learners across disciplines and experiences. In a time of increasing democratization of knowledge, universities are no longer the only source for learning - but they are critically important ones. They provide a place for scholarship, research, and innovation. They provide a place where students learn and develop human values. They provide a place where members of society - students, faculty, organizations, and communities - come together to engage in dialogue, generate and cross-pollinate ideas, and solve problems. The university must continue to provide a space where the next generation of leaders can learn to think openly and make meaning of an uncertain future,

152 If it is possible to suggest a positive sense in which the word indoctrination can be used, I would invoke it here. Legal education requires a wholehearted commitment to learning, understanding, and working in the legal mindset, at least in the beginning of one's practice. Like all efforts towards expertise, basic facility precedes competence, which in turn precedes expertise. At the expert level, one can begin to experiment and play with concepts, but as with all arts, it is hard to do so convincingly without having mastered the basics.

153 Marta Urquilla, “To Build Leaders for Social Impact, Universities Must Adapt," Stanford Social Innovation Review (21 December 2016), online: $<$ https://ssir.org/articles/entry/to_build_leaders_for_social_impact_universities_must_adapt $>$. 
and to marry scholarship and concern for others to the practical goal of achieving social impact. $^{154}$

Design thinking is one of these "new modalities," and it is an integral and essential feature of innovation. Learning about design thinking - learning how to do it and, most importantly, within the learning environment a law school provides and having an opportunity through practicums, clinics, labs, and workshop-based courses to practice it - these features of law school are also what makes it a natural starting place to begin such training in an applied field like law.

Razzouk and Shute are interested in the applicability and importance of design thinking generally in promoting the problem-solving skills students need to succeed after graduation. ${ }^{155}$ They suggest that design thinking, systems thinking, and collaborative team skills are necessary to this preparation. They are also of the view that current educational practices mostly follow an outdated pedagogy that stresses content over engagement. Ultimately, Razzouk and Shute call for education generally to move beyond its traditional narrow focus to consider educationally valuable skills that follow the design-thinking approach. ${ }^{156}$ Their observations have applicability to the study of law as well. The CBA also recognized this need for an expanded conceptualization of legal education in its Futures report, which expressly addresses the issue. In its sixteenth recommendation, the CBA states:

An integrated, practical approach, including multidisciplinary skills training, should be incorporated into [law school] curricula to provide "translational knowledge" - the ability to turn critical knowledge of legal concepts, regulatory processes, and legal culture into actual problem-solving ability in practice. ${ }^{157}$

Design thinking offers one path into development of this translational knowledge skill set and comes with a highly developed body of theory and practice that could be adapted to both common law and civil law education curricula. For example, deliberately and expressly adding the process of abductive reasoning to the repertoire of lawyers' thinking skills and affording low risk, high engagement opportunities to utilize such skills while in law school is one concrete way of bringing translational knowledge skills into the profession.

\section{E. Design Thinking Is Useful Because It Is Adaptable to Issues in Service Provision and Law Is about Service Provision}

Designers recognize the significance of their engagement with systems when they contemplate the evolution of their discipline and its application in non-traditional areas. ${ }^{158}$ Their work in the design of service provision is an example of applying design thinking and theories to human experiences and systems, as opposed to tangible artefacts. ${ }^{159}$ Brown recognizes the "intrinsically human-centered" nature of design thinking as a discipline that can effectively channel human emotion to enrich itself and the

154 Ibid [emphasis added].

155 Razzouk \& Shute, supra note 24 at 330-348.

156 Ibid at 331, 343-344.

157 CBA Legal Futures Initiative, supra note 12.

158 Cross, supra note 51 at 75.

159 For a consideration of design thinking and social innovation in service delivery in multi-disciplinary stakeholder contexts, see CF Yang \& TJ Sung, "Service Design for Social Innovation through Participatory Action Research" (2016) 10:1 International Journal of Design 21. 
experience of its users. ${ }^{160}$ This idea of "experience engineering,"161 or, more prosaically, service delivery design, has much to offer law, particularly in regard to increasing access to justice. In some senses, accessto-justice issues are quintessential service delivery problems. Seeing the problem through this lens does not trivialize it; it affords us another way to approach the problem.

The Disney organization has made itself legendary as a pre-eminent experience engineer in its famous theme parks. So much so that its techniques have been studied to assist the design of, among other things, airport security check-in processes. ${ }^{162}$ Of course, no one is advocating the "Disney-fication" of the legal system, but the idea of using private sector service delivery design initiatives is something that the legal system can certainly draw from. This means not just in the area of law firms' delivery of services to their clients, although this is significant and important. It includes the delivery of services throughout the system, including in the courts, ${ }^{163}$ in legal support services, in legal education for laypersons, and in training to provide such services. In considering these loci of service delivery, we also begin to find ways to broaden access to these services for those precluded, and we could thus impact access to justice.

The idea of service delivery design is something that has evolved naturally throughout history, although it gained traction as a movement during the second Industrial Revolution. In their book Service Design: From Insight to Implementation, authors Andy Polaine, Lavrans Løvlie, and Ben Reason talk about the transition that occurred with the "1920s generation of industrial designers" who sought to focus their attention on designing services rather than on designing products. ${ }^{164}$ In doing so, these designers attempted to "humanize the technology of their day to meet the material needs of their generation," though they encountered significant challenges along the way finding that services and products are "completely different animals." " 65 Service designers like these authors locate the problem in the "siloed" organization of businesses producing products. While this division into silos may make sense to the business units, it makes no sense to the customer, who sees the business offering as one experience. This silo structure, which is replicated by service organizations in the private, public, and non-profit sectors, impedes, rather than facilitates, good service experience. In order to design better services, it is necessary to see the entire system as one thing and the entire service experience as one experience for the customer, client, or stakeholder. Systems thinking is an essential aspect of the analysis underlying better service design.

The Open Law Lab specifically addresses the issue of service delivery in law in its project devoted to access-to-justice innovations. In this project, the lab poses the following questions: how might we design products and services that allow for better delivery of legal services to more people in society and are there ways to do it using technology and do-it-yourself measures? The project also looks at interventions that have been tried in the past as a means of informing the trajectory of future innovations. ${ }^{166}$ Stemming

160 Brown, Change by Design, supra note 26 at 115.

161 Ibid at 116.

162 For more information on how Disney design principles have impacted security check-in procedures, see Donald A Norman, "The Psychology of Waiting Lines" (21 August 2008), online: <http://www.jnd.org/ms/Norman\%20-

The\%20Psychology\%20of\%20Waiting\%20Lines.pdf>; see also Yves Duguay, "Checkpoint Queuing: Learning Lessons from Walt Disney," HCiWorld (1 June 2014), online: <http:/www.hciworld.ca/fr/publications/airport-authorities-investplanning-design-security-checkpoints-future/>.

163 For an example of how the courts have leveraged design innovation in their provision of services for self-represented litigants, see Pro Bono Ontario, "Going to Court," Law Help Ontario initiative, online: <https://www.probonoontario.org/lawsuits-and-disputes/>.

164 Andy Polaine, Lavrans Løvlie \& Ben Reason, Service Design: From Insight to Implementation (Brooklyn: Rosenfeld Media, 2013) at 18.

165 Ibid.

166 See Open Law Lab, “Access to Justice Innovations,” online: <http://www.openlawlab.com/project-topics/access-tojustice-innovations/>. 
from its design service mandate, the lab also profiled a "court hack" (that is, legal hackathon) hosted in Salt Lake City, which brought technologists and lawyers together to create products that could improve court user experience. ${ }^{167}$ This is an example of applying design thinking and techniques to service provision in law - specifically, in court processes.

Design thinking can also be applied to improve access to other aspects of the legal system. Osgoode Hall Law School in Toronto has also begun its own integration of design thinking into its legal education work with the recent "Orphan Works Licensing Portal Hackathon."168 Co-sponsored by Osgoode's Intellectual Property and Technology Program and the Copyright and International Trade Policy Branch of the Department of Canadian Heritage, the hackathon was focused on developing options for new online systems to process the licensing of Canadian orphan works. The Hackathon expressly adopted the design thinking user-centric design process pioneered by Stanford's d.school to "infuse some genuine creativity" into the "hack." 169 A second example of Osgoode Hall integrating design thinking into its educational curricula is its legal information technology course, ${ }^{170}$ which has as its objective viewing and using "technology as a tool to enhance access to justice." Building on Hagan's work, the class employed a design-process approach to two topics in a "mini-design lab," which focused on educating and empowering students to design their own tech solution to a justice problem. ${ }^{171}$

At the Michigan State University [MSU] College of Law, the course "designing legal services" (formerly "design thinking for legal services"), created by Adjunct Professor Joshua Kubicki, describes the kind of integration of design thinking into legal education that is suggested in this article. ${ }^{172}$ The course offering describes itself as intending to equip students with skills and knowledge to tackle the problems encountered by the ever-changing landscape of the legal services market. As a means of doing this, the class focuses on design thinking and its methodologies. ${ }^{173}$ Kubicki's course is part of a constellation of legal innovation initiatives at MSU, which includes LegalRnD, an innovation centre dedicated to improving the delivery of legal services through systems research and development. ${ }^{174}$ LegalRnD, like the Legal Design Lab based at Stanford Law School \& d.school are examples of academia (with its opportunities for research and development) and legal service delivery intersecting fruitfully. ${ }^{175}$

Building on these examples and on other experiments in legal service provision, such as Pro Bono Ontario's Self-Represented Litigants program, ${ }^{176}$ design thinking could be employed to create new ways to access various subsystems in the legal system. For example, small claims court processes could be

167 See Margaret Hagan, "Courthack in Salt Lake City with the National Center for State Courts" (25 March 2016), online: Open Law Lab <http://www.openlawlab.com/2016/03/25/courthack-in-salt-lake-city-with-the-national-center-for-statecourts $/>$.

168 See IP Osgoode, “Orphan Works Licensing Portal Hackathon,” online: <http://iposgoodehackathon.info.yorku.ca $>$.

169 Ibid.

170 For an explanation of this course offering at Osgoode, see Hannah DeJong, "Osgoode's New Law Course Prepares Students for the Future of Law" (undated), online: Winkler Institute for Dispute Resolution $<$ https://winklerinstitute.ca/osgoodes-new-law-course-prepares-students-for-the-future-of-law/ $>$.

171 Dean Lorne Sossin, “Justice by Design” (2 June 2015) (blog), online: <http://deansblog.osgoode.yorku.ca/2015/06/justice-by-design/>.

172 See also Legal Design Lab: Consumer Contracts, online: $<$ https://law.stanford.edu/stanford-lawyer/articles/legal-designlab-consumer-contracts/ $>$, a new course at Stanford Law School that explores issues of consumer contracts on the Internet.

173 For the full course description as seen on the Michigan State University College of Law website, see "Design Thinking for Legal Services," online: <https:/www.law.msu.edu/news/2014/Legal-Design-Services.html>.

174 See "LegalRnD: The Center for Legal Services Innovation," online: <http://legalrnd.org> retrieved May $29,2016$.

175 See Legal Design Lab, supra note 31.

176 See Pro Bono Ontario, "Self-Represented Litigants," online $<$ https://www.probonoontario.org/2016/05/17/slider-5-2/> 
streamlined for non-complex cases using and adapting models of online dispute resolution [ODR] already in use in other jurisdictions around the world. In Canada, where telecommunications is a particularly necessary and robust feature of everyday life, the concepts of ODR could be combined with the strategic use of services such as Skype in order to provide a hybrid of written and virtual "in person" processes that could maximize access as well as buy-in by end-users, who would not sacrifice all aspects of being heard.

Similarly, disputes over the administrative or provincial enforcement of laws such as parking tickets or bylaw complaints and enforcement might also benefit by such hybrid designs. Not all problems of access to justice will be solved through the use of writing-based, online processes; some require in-person solutions. Enforcement of employment laws and regulations is currently dealt with in the courts and before tribunals such as the Ontario Labour Relations Board. However, both of these systems use mediation as a method to reduce the number of cases actually heard. It is by no means clear though that it is necessary to physically convene the parties in one place in order to carry out a robust and useful mediation process. Virtual meeting applications already exist commercially and are an area in which design thinking could be applied to existing platforms in order to create a legal mediation product specifically designed for this purpose.

In another sphere of legal activity - the efficient provision of legal services - design thinking can also provide a basis for new and different models of service provision within law firms. Mark Szabo makes a case not just for seeing the fruitful analogies between law firms and creative businesses such as communications firms but also for actually running law firms more like these counterparts. ${ }^{177}$ Leveraging collaboration as a method borrowed from design thinking and communications firms, which in turn arguably enhances efficiency and delivers a superior product, Szabo suggests ways in which compensation structures can enhance collaboration. At the same time, he suggests that as expert legal communicators law firms expressly consider their target audiences to explicitly encompass the decision makers and not just their clients. These are only a few examples where design thinking, with the end-user in mind, could be applied to generate better, faster, more accessible user experiences in law.

\section{CONCLUSIONS}

The practice of law itself is a design process, wherein lawyers' problems solve, or design, solutions for clients. Substantive and procedural law are integrated into a highly designed system or series of systems for "doing law," such as argumentation, litigation, legislation, and so on. Explicitly recognizing that we are engaged in design work in law makes possible a more deliberate approach to innovation in problematic situations and contexts in law that require us to do things differently. The systems through which law is practised can also be deliberately designed, and, in this possibility, we can begin to generate answers to important questions such as access to justice.

Design thinking represents both challenges to, and opportunities for, law. Fundamentally though, so much more could be achieved using design theory and design thinking, especially if we imbued law with these ways of thinking, if we "got them into the water supply."178 One deliberate way in which we could do this would be to include design thinking and innovation as express areas of study in legal education. In order to do so, however, we need a working knowledge of what design thinking means. This article attempts to provide an introduction to a set of ideas and concrete practices that can help identify and ultimately overcome the problems that plague our legal system. While this article develops a view of

177 Szabo, supra note 40.

178 I am particularly grateful and indebted to Frances Westley for this concept, which sums up so nicely the idea of deeply embedding a new set of concepts and skill sets in an existing context. 
design thinking in law that offers considerable scope for its application, it is fundamentally an introduction to the ideas involved rather than a complete syllabus for study or a set of case studies. Indeed, the application of design thinking in law is a newly emerging field. I hope through this article to encourage a greater familiarity with these ideas and a willingness to apply them in the everyday work of law.

Design thinking brings a more deliberate and, at the same time, more creative process to the project of law, writ large. It is scalable, with application from education through to law practice, from individual issues in litigation to systemic change, and it can be applied across subject areas, sectors, institutions, and domains. It is expressly intended for use in approaching and solving complex problems. Design thinking renders transparent and workable the creative and generative thinking processes, tools, techniques, strategies, and stances that we can employ to solve problems in law. We may even be employing some of these in our work already. That we can find multiple apt analogies between design thinking and law and legal thinking is what makes law so ripe for using design thinking in problem solving. Design thinking opens our minds to our capacity to design and create innovations in law. In its versatility, adaptability, and applicability, design thinking offers an exciting, new, and engaging way to approach and solve the complex, wicked problems of twenty-first-century law. Design thinking will help us get unstuck and build better law. 